Aus der Abteilung Prothetik,

(Direktor: Prof. Dr. med. dent. Ralf Bürgers)

im Zentrum Zahn-, Mund- und Kieferheilkunde

der Medizinischen Fakultät der Universität Göttingen

\title{
Knockdown von Runx2 durch RNA-Interference in Chondrogenen Progenitor-Zellen
}

\author{
INAUGURAL-DISSERTATION \\ zur Erlangung des Doktorgrades für Zahnheilkunde \\ der Medizinischen Fakultät \\ der Georg-August-Universität zu Göttingen \\ vorgelegt von \\ Moritz Klein \\ aus Siegburg
}

Göttingen 2014 
Dekan: Prof. Dr. rer. nat H. K. Kroemer

1. Berichterstatter: Prof. Dr. med. N. Miosge

2. Berichterstatter/in: Prof. Dr. med. Dr. med. dent. K. G. Wiese

3. Berichterstatter/in:

Tag der mündlichen Prüfung: 


\section{Inhaltsverzeichnis}

Inhaltsverzeichnis

1.1 Der Gelenkknorpel 1

1.1.1 Funktion und Aufbau 1

1.1.2 Chondrogenese 4

1.2 Osteoarthritis 5

1.2.1 Allgemein 5

1.2.2 Ursachen 5

1.2.3 Pathologische Veränderungen 6

1.2.4 Therapie 8

$\begin{array}{ll}1.3 \text { Chondrogene Progenitor-Zellen } & 9\end{array}$

1.4 Runt-related transcription factor 2 (Runx2) 11

1.5 SRY-related HMG-box gene 9 (Sox9) 13

$\begin{array}{ll}1.6 \text { RNA-Interference } & 15\end{array}$

1.6.1 Allgemein 15

1.6.2 Mechanismus 15

1.6.3 Verwendung 16

$\begin{array}{ll}\text { 1.7 Plasmide / Vektoren } & 17\end{array}$

$\begin{array}{ll}\text { 1.8 Frage- und Aufgabenstellung } & 20\end{array}$

2. Material und Methoden 21

2.1 Zellkultur 21

2.2 Das Plasmid 21

2.2.1 Allgemein 21

2.2.2 si-RNA 22

2.3 Plasmid-Amplifikation 22

2.3.1 Transformation von Bakterien 22

2.3.2 Plasmid-Isolation 23 
2.4 Transfektion 23

2.4.1 Allgemein 23

2.4.2 Vorbereiten der Zellen 24

2.4.3 Transfektions-Protokoll 25

2.4.4 Kontrolle der Transfektion und Selektionierung 25

2.5 RT-PCR 25

2.5.1 Allgemein 25

2.5.2 m-RNA-Isolation aus Zellen 26

2.5.3 c-DNA Synthese $\quad 27$

2.5.4 Verwendete Primer 27

2.5.5 Protokoll der PCR 28

2.5.6 Statistik 29

2.6 Western Blot 29

2.6.1 Allgemein 29

2.6.2 Probenvorbereitung 30

2.6.3 Natriumdodecylsulfat-Polyacrylamidgelelektrophorese (SDS-Page) 30

2.6.4 Der Blot 33

2.6.5 Proteinfärbung auf PVDF-Membran $\quad 34$

2.6.6 Immunreaktion $\quad 34$

$\begin{array}{ll}\text { 3.Ergebnisse } & 37\end{array}$

$\begin{array}{ll}3.1 \text { Transfektion } & 37\end{array}$

3.2 PCR 42

3.3 Western Blot 44

4. Diskussion $\quad 47$

4.1 Allgemein $\quad 47$

4.2 Effizienz und Stabilität der Transfektion 47

4.3 Plasmid-Vergleich $\quad 49$

4.4 Runx2-Knockdown 50

4.5 Effekt des Runx2-Knockdown 52 
6. Abbildungsverzeichnis

7. Tabellenverzeichnis

8. Literaturverzeichnis 


\section{Abkürzungsverzeichnis}

\begin{tabular}{|c|c|c|}
\hline ADAMTS 5 & $\rightarrow$ & ADAM metallopeptidase with thrombospondin Typ 1 Motif 5 \\
\hline APS & $\rightarrow$ & Ammoniumperoxodisulfat \\
\hline BMP6 & $\rightarrow$ & Bone morphogenetic protein 6 \\
\hline Cbfa1 & $\rightarrow$ & Core binding factor a1 \\
\hline $\mathrm{cm}^{2}$ & $\rightarrow$ & Quadratzentimeter \\
\hline CPC & $\rightarrow$ & Chondrogene Progenitor-Zellen \\
\hline ct & $\rightarrow$ & cycle threshold \\
\hline DMEM & $\rightarrow$ & Dulbecco`s modified Eagle Medium \\
\hline DNA & $\rightarrow$ & Desoxyribonukleinsäure \\
\hline ds-RNA & $\rightarrow$ & doppelsträngige Ribonukleinsäure \\
\hline EDTA & $\rightarrow$ & Ethylendiamintetraessigsäure \\
\hline FBS & $\rightarrow$ & Fetal bovine Serum \\
\hline GFP & $\rightarrow$ & green fluorescenting protein \\
\hline HPRT-1 & $\rightarrow$ & Hypoxanthin-Phosphoribosyl-Transferase 1 \\
\hline HMG & $\rightarrow$ & High-mobility-group \\
\hline $\mathrm{kDa}$ & $\rightarrow$ & Kilodalton \\
\hline LPL & $\rightarrow$ & Lipoproteinlipase \\
\hline L-Sox5 & $\rightarrow$ & long SRY-related HMG-box gene 5 \\
\hline $\mathrm{mA}$ & $\rightarrow$ & Milliampere \\
\hline $\mathrm{mg}$ & $\rightarrow$ & Milligramm \\
\hline$\mu g$ & $\rightarrow$ & Mikrogramm \\
\hline $\mathrm{ml}$ & $\rightarrow$ & Milliliter \\
\hline MMP & $\rightarrow$ & Matrixmetalloproteinase \\
\hline m-RNA & $\rightarrow$ & messenger Ribonukleinsäure \\
\hline $\mathrm{NaCl}$ & $\rightarrow$ & Natriumchlorid \\
\hline $\mathrm{Nm}$ & $\rightarrow$ & Newtonmeter \\
\hline $\mathrm{Nm}$ & $\rightarrow$ & Nanometer \\
\hline PBS & $\rightarrow$ & phosphate buffert saline \\
\hline PCR & $\rightarrow$ & Polymerase Chain Reaktion \\
\hline pmol & $\rightarrow$ & pikomol \\
\hline PPARy & $\rightarrow$ & Peroxisom-proliferator-aktivierter Rezeptor $\gamma$ \\
\hline PVDF & $\rightarrow$ & Polyvinylidenfluorid \\
\hline
\end{tabular}




\begin{tabular}{|c|c|c|}
\hline RNA & $\rightarrow$ & Ribonukleinsäure \\
\hline Rpm & $\rightarrow$ & Rounds per minute \\
\hline Runx2 & $\rightarrow$ & Runt-related transcription factor 2 \\
\hline SDS-Page & $\rightarrow$ & sodiumdodecylsulfate-polyacrylamidegelelectrophoresis \\
\hline sh-RNA & $\rightarrow$ & short hairpin-Ribonukleinsäure \\
\hline si-RNA & $\rightarrow$ & small interfering-Ribonukleinsäure \\
\hline Sox9 & $\rightarrow$ & SRY-related HMG-box gene 9 \\
\hline SRY & $\rightarrow$ & Sex determing region of $Y$ \\
\hline Taq & $\rightarrow$ & Thermus aquaticus \\
\hline TEMED & $\rightarrow$ & Tetramethylethylendiamin \\
\hline TGF $\beta 3$ & $\rightarrow$ & Transforming-Growth-Factor $\beta 3$ \\
\hline TNF & $\rightarrow$ & Tumornekrosefaktor \\
\hline TRIS & $\rightarrow$ & Tris(hydroxymethyl)-aminomethan \\
\hline
\end{tabular}




\section{Einleitung}

\subsection{Der Gelenkknorpel}

\subsubsection{Funktion und Aufbau}

Der Gelenkknorpel ist eine spezielle Art von Bindegewebe, welches an den Enden langer Knochen zu finden ist. Er schützt den darunterliegenden Knochen vor übermäßiger Belastung und verteilt die bei der Gelenkbewegung auftretenden Kräfte. Durch seine sehr glatte Oberfläche, welche mit Gelenkflüssigkeit überzogen ist, wird die Reibung während Bewegungen verringert.

Das Knorpelgewebe besteht aus Knorpelzellen, den Chondrozyten, und extrazellulärer Matrix, wobei die Chondrozyten einen Volumenanteil von nur etwa fünf Prozent im Gelenkknorpel eines Erwachsenen einnehmen. Die extrazelluläre Matrix besteht zu 70 Prozent aus Wasser sowie aus quervernetzten Kollagen-Fasern (ca. 90 Prozent Kollagen-Typ II, ca. 10 Prozent Kollagen-Typ VI, IX, X und Kollagen-Typ XI), Proteoglykanen (vor allem Aggrecan) und Glykoproteinen. Der Gelenkknorpel enthält keine Blut- oder Lymphgefäße und keine Nervenfasern. Daraus folgt, dass die Ernährung und der Abtransport von Stoffwechselprodukten über Diffusion durch die extrazelluläre Matrix erfolgt (Kuettner 1992).

Betrachtet man den Gelenkknorpel im Mikroskop von der Oberfläche bis zum subchondralen Knochen, so lassen sich horizontal vier verschiedene Zonen unterscheiden: Die oberflächliche Zone, charakterisiert durch kleine, abgeflachte Chondrozyten, die mittlere Zone, in welcher die Chondrozyten runder sind und die tiefe Zone mit runden Chondrozyten, welche in Säulen oder Gruppen angeordnet sind (Goldring, M B und Marcu 2009). Zwischen der tiefen Zone und dem darunter liegenden Knochen befindet sich die kalzifizierte Zone mit runden Chondrozyten in nicht-kalzifizierten Lakunen. Die Grenze zwischen der tiefen und der kalzifizierten Zone ist im Lichtmikroskop als eine gewellte Linie zu erkennen, die so genannte Tidemark (Poole 1997). Chondrozyten liegen in Einheiten vor, welche als Chondrone bezeichnet werden. In einer solchen Einheit wird der Chondrozyt von einer perizellulären Matrix umgeben. Die Anzahl der Zellen in einem Chondron variiert zwischen den verschiedenen Knorpelschichten (Poole 1997). 


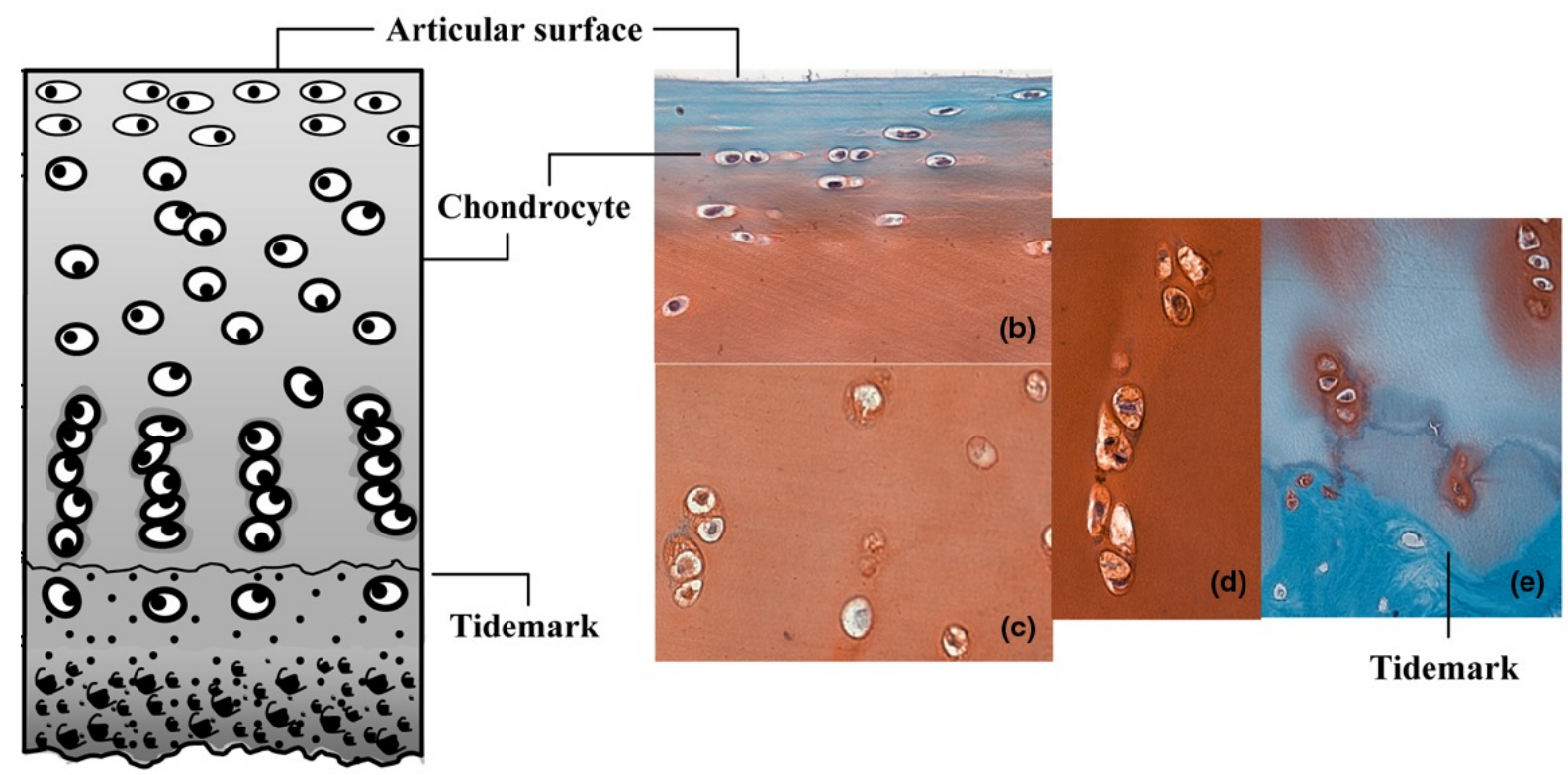

Abbildung 1: (Grogan et al. 2009, R85) Gelenkknorpel im Längsschnitt schematisch und mikroskopisch. Oberfächliche Zone (b), mittlere Zone (c) , tiefe Zone (d) und tiefe mit kalzifizierter Zone (e)

Eine Besonderheit der Chondrozyten ist, dass Sie keine direkten Zell-zu-ZellKontakte besitzen. Somit ist eine Kommunikation der Zellen untereinander nur über die extrazelluläre Matrix möglich (Kuettner 1992).

Die mechanischen Eigenschaften des Knorpels resultieren aus der Zusammensetzung der extrazellulären Matrix. Die Chondrozyten selbst sind daran nur indirekt beteiligt, indem sie Synthese und Abbau der extrazellulären Matrix steuern (Hall et al. 1996). Es lässt sich eine perizelluläre, territoriale und interterritoriale Matrix unterscheiden. Auch die Matrix-Zusammensetzung ist in diesen drei Kompartimenten verschieden. Die perizelluläre Matrix liegt am nächsten zur Zellmembran der Chondrozyten und besteht aus vielen Proteoglykanen und wenigen Kollagen-Fibrillen. Sie wird von der territorialen Matrix umgeben, welche mit einem korbähnlichen Geflecht aus Kollagen-Fibrillen den perizellulären Bereich umschließt, und die größte Menge Kollagen-Typ IV aufweist. Den größten Anteil hat die interterritoriale Matrix, welche die meisten Kollagenfibrillen und Proteoglykane enthält (Kuettner 1992).

Im Gelenkknorpel haben die verschiedenen Kollagene zusammen einen Anteil von ca. 50 Prozent des Trockengewichtes des Gewebes. Wie schon beschrieben, macht den größten Teil davon Kollagen-Typ II aus. Dieses Kollagen gehört zu den Fibrillenformenden Kollagenen und ist zusammengesetzt aus drei identischen Polypeptidketten, welche jeweils aus einer Tripelhelix bestehen. In den tieferen Schichten des 
Knorpels bildet Kollagen-Typ II dickere, in den oberflächlichen Schichten dünnere Fibrillen.

Kollagen-Typ VI bildet Mikrofibrillen, welche sich in unmittelbarer Umgebung der Chondrozyten und Chondrone konzentrieren. Kollagen-Typ IX hat die Funktion eines Brückenmoleküls, da es zur Oberfläche von Kollagen-Typ-II-Fibrillen kovalente Bindungen aufbaut. Dadurch hat es auch eine wichtige Funktion bei der Stabilisierung des kollagenen Netzwerks. Kollagen-Typ X wird in gesundem Gelenkknorpel ausschließlich von hypertrophen Chondrozyten in der kalzifizierten Zone synthetisiert (Kuettner 1992). In osteoarthritischem Knorpel hingegen wird Kollagen-Typ X auch von Zellen synthetisiert, welche weiter oben liegen, vor allem im Bereich von ZellClustern (Gannon et al. 1991).

Das gesamte Netzwerk der Kollagen-Fibrillen bildet die Grundlage für die Stabilität von Form und Volumen des Gewebes.

Proteoglykane sind stark glykosylierte Glykoproteine, welche sehr hydrophil sind. In der extrazellulären Matrix des Knorpels liegen sie in einer unterhydrierten Form, komprimiert innerhalb des fibrillären Kollagennetzwerks, vor. Sie dienen so zur Stabilisierung des Gewebes und geben dem Knorpel die Eigenschaft, sich reversibel zu verformen. Das im Knorpel am häufigsten vorkommende Proteoglykan ist Aggrecan und besteht aus einem Proteinkern mit vielen kovalent gebundenen Glykosaminglykan-Ketten. 90 Prozent dieser Glykosaminglykan-Ketten machen Keratan-Sulfat und Chondroitin-Sulfat aus. Der Proteinkern hat drei globulläre Domänen (G1-3) (Kuettner 1992). Aggrecan ist in der Lage, mit seiner G1-Domäne über ein Linkprotein an Hyaluronsäure, ein Polysaccharid, zu binden. So können mehr als 200 AggrecanMoleküle an ein Molekül Hyaluronsäure binden und so sehr große Aggregate bilden (Knudson und Knudson 1993). Weitere Proteoglykane neben Aggrecan sind Biglykan, Decorin und Fibromodulin. Sie können mit anderen Molekülen der extrazellulären Matrix interagieren. So sind Decorin und Fibromodulin an der Oberfläche der Kollagen-Fibrillen lokalisiert und nehmen Einfluss auf Struktur und Organisation der extrazellulären Matrix (Kuettner 1992). Eine der wichtigsten Funktionen der Proteoglykane ist, dass sie durch ihre starke Ladung eine hoch-osmotische Umgebung bilden und so Flüssigkeit im Gewebe halten (Heinegard 2009). 


\subsubsection{Chondrogenese}

Die Chondrogenese beschreibt die Bildung von Knorpelgewebe während der Embryonalentwicklung und führt in einem Prozess, welcher als enchondrale Ossifikation bezeichnet wird, zur Bildung des Skelettsystems (Goldring, M B et al. 2006). Der Beginn ist durch die Kondensation und Proliferation mesenchymaler Stammzellen charakterisiert, die sich weiter zu Chondrozyten differenzieren, wodurch sich eine knorpelige Vorlage bildet, welche im Laufe der Ossifikation durch Knochen ersetzt wird. Die Chondrozyten werden hypertroph und sezernieren mineralisierte extrazelluläre Matrix. Am Rand des Knorpelgewebes liegen Zellen, welche sich zu Osteoblasten differenzieren und die Chondrozyten umgeben. Von außen wandern Blutgefäße ein und der Knorpel wird von Osteoklasten und Osteoblasten durch Knochen ersetzt (Wuelling und Vortkamp 2009). Dieser Vorgang beginnt in dem zentralen Wachstumszentrum, der Epiphyse, und später in den distalen Wachstumszentren, den Diaphysen. Die zwischen Epiphyse und Diaphyse liegende Wachstumsfuge schließt sich im Laufe des Lebens und eine dünne Schicht Knorpel verbleibt an den Enden des Knochens, welche die Gelenkoberfläche bildet (Hollander et al. 2010).

Alle diese Vorgänge unterliegen einer komplexen Kontrolle durch Zell- Zell- und ZellMatrix-Interaktionen (Goldring, M B et al. 2006), sowie dem Einfluss einer Reihe von Wachstums- und Transkriptionsfaktoren (Wuelling und Vortkamp 2009). 
a

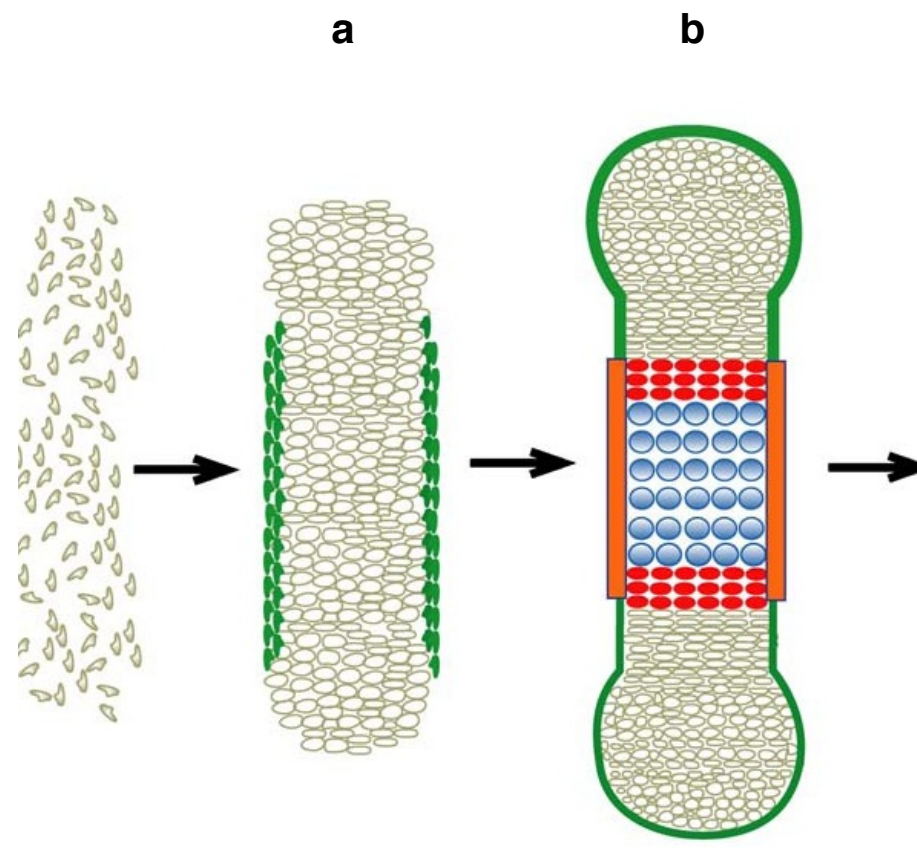

C

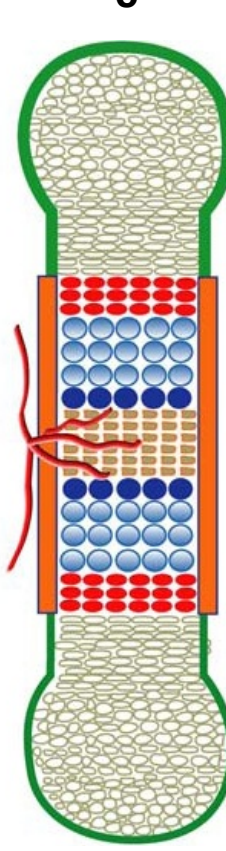

d

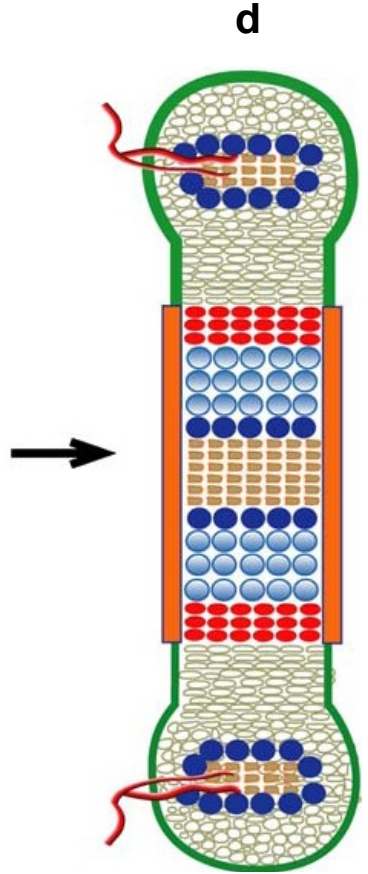

Abbildung 2: (Wuelling und Vortkamp 2009, S.626) Chondrogenese. a Kondensation mesenchymaler Stammzellen. b Differenzierung zu proliferierenden (grau), prähypertrophen (rot) und hypertrophen Chondrozyten umgeben von Perichondrium (grün) und Periost (orange). c Einsprossen von Gefäßen und beginnende Knochenbildung im zentralen Wachstumszentrum. $\mathbf{d}$ Knochenbildung in den distalen Wachstumszentren

\subsection{Osteoarthritis}

\subsubsection{Allgemein}

Die Mehrheit aller über 65-Jährigen zeigt Anzeichen von Osteoarthritis. Am häufigsten betroffen sind Hände, Knie, Hüften und die Wirbelsäule. Symptomatisch sind allgemeine Entzündungszeichen, Schmerzen, Steifheit und funktionelle Einschränkungen. Die betroffenen Gelenke sind gekennzeichnet durch Degeneration des Gelenkknorpels, Entzündung und Veränderungen im subchondralen Knochen (Felson 2006).

\subsubsection{Ursachen}

Die Hauptursache, welche zu der Entstehung von Osteoarthritis führt, scheint das Alter zu sein. Daneben spielen aber auch mechanische Faktoren wie Über- oder Fehl- 
belastung und genetische Komponenten eine Rolle (Goldring, M B und S R Goldring 2007).

Chondrozyten sorgen in gesundem Gelenkknorpel für eine stetige Neusynthese der Matrix-Komponenten. Es herrscht ein Gleichgewicht zwischen anabolem und katabolem Stoffwechsel. Im Alter nimmt das Regenerationspotential der Chondrozyten ab und es kommt zu strukturellen Veränderungen in der Matrix, was sich in einer verminderten Festigkeit niederschlägt. Diese altersbedingten Veränderungen führen nicht zwangsläufig zur Entstehung von Osteoarthritis, machen das Gelenk jedoch anfälliger dafür (Martin und Buckwalter 2002).

Eine Über-, beziehungsweise Fehlbelastung des Gelenks führt zum Abbau von Proteoglykanen und Schäden im Kollagennetzwerk, sowie einer verminderten Synthese der Matrix-Proteine (Guilak et al. 2004). Aufgrund dieser Schädigungen kommt es zu einer vermehrten Produktion von entzündungsfördernden Mediatoren und knorpelabbauenden Proteinasen (Fitzgerald 2004). Des weiteren haben Chondrozyten Rezeptoren, die auf mechanische Reize reagieren, welche gleichzeitig Rezeptoren für Bestandteile der extrazellulären Matrix sind, und die Produktion von entzündungsfördernden Zytokinen und Chemokinen stimulieren (Pulai et al. 2005).

Es gibt auch Hinweise auf genetische Ursachen für einen früheren Beginn von Osteoarthritis (Valdes et al. 2006). Epidemiologische Studien belegen, dass eine genetische Disposition bei einer Erkrankung an Osteoarthritis bis zu 70 Prozent ausmachen kann. Weiterhin können Gendefekte, welche die Knorpel- und Skelettentwicklung betreffen, zu einer Reihe von kongenitalen Knorpeldysplasien führen. Die Folgen dieser Defekte, wie zum Beispiel Gelenkfehlstellungen, können zu einem Verlust von Gelenkknorpel führen und so zu einer früh beginnenden Osteoarthritis ( $\mathrm{Li}$ et al. 2007).

\subsubsection{Pathologische Veränderungen}

Die makroskopischen Veränderungen des Gelenkknorpels bei einer Erkrankung an Osteoarthritis äußern sich durch weicheren Knorpel, Ulzerationen und Fibrillation. Mikroskopisch sieht man Spalten im Knorpel, tote Chondrozyten, aber auch Bereiche mit proliferierenden Chondrozyten (Horton et al. 2006). 
Physiologischerweise herrscht im Knorpelgewebe ein Gleichgewicht zwischen Abbau und Neusynthese der extrazellulären Matrix. In osteoarthritisch-verändertem Knorpel ist dieses Gleichgewicht gestört. Sowohl Abbau als auch die Syntheseaktivität sind erhöht (Sandell und Aigner 2001). Eine gesteigerte Synthese von knorpelspezifischen Komponenten wie Kollagen-Typ II, IX, XI und VI, sowie Aggrecan, stellt den Versuch der Chondrozyten dar, das Knorpelgewebe zu regenerieren. Folge der gesteigerten Aktivität sind Fibrillationen, das Auftreten von Zell-Clustern und eine veränderte Matrixzusammensetzung (Goldring, M B und S R Goldring 2007), welche unter anderem durch das Vorkommen von atypischen Kollagenen, wie zum Beispiel Kollagen-Typ $X$ oder -Typ III charakterisiert ist. Kollagen-Typ $X$ ist in gesundem Knorpelgewebe charakteristisch für hypertrophe Chondrozyten in der kalzifizierten Zone unterhalb der Tidemark und ist auch ein spezifischer Marker für die Hypertrophie der Chondrozyten in der Wachstumsfuge.

Der gesteigerte Abbau in osteoarthritisch-verändertem Knorpel resultiert aus der gesteigerten Produktion von Proteinasen, wie den Metalloproteinasen MMP-1, -3, -8, -13 sowie Aggrecanasen, vor allem ADAMTS-5 (Cawston und Wilson 2006). Den größten Anteil am Kollagenabbau, vor allem von Typ-II Kollagen, hat die MMP-13 (Billinghurst et al. 1997).

Osteoarthritis wird nicht als klassische entzündliche Arthropathie bezeichnet, da in der Gelenkflüssigkeit keine neutrophilen Granulozyten zu finden sind und eine systemische Manifestation fehlt (Felson 2006). Trotzdem spielt die Synovitis eine wichtige Rolle in der frühen und späten Osteoarthritis. Sie ist durch aktivierte B- und T-Lymphozyten und eine Überexpression von entzündungsfördernden Mediatoren, wie Interleukin-1, (IL-1) IL-6, IL-8, IL-17, IL-18, Tumor-Necrosis Factor alpha (TNF-a) oder Stickstoffmonoxid, gekennzeichnet (Benito 2005). Die Synovitis ist ein wichtiger Faktor bei der Entstehung des Ungleichgewichtes von anabolem und katabolem Stoffwechsel der Chondrozyten (Loeser 2006). Es ist belegt, dass ein Zusammenhang zwischen dem vermehrten Auftreten von katabolen Enzymen und entzündungsfördernden Mediatoren besteht (Goldring, M B und S R Goldring 2007).

Nicht nur der Knorpel und die Synovia, sondern auch der subchondrale Knochen zeigt Veränderungen. Es handelt sich um Sklerosierung, die Bildung von Osteophyten und subchondralen Zysten (Hill et al. 2001). Des Weiteren kommt es zu einer Vaskularisierung im Bereich der Grenze zwischen Gelenkknorpel und subchondralem 
Knochen, was zu einem Vorschieben der Tidemark führt und so zu einer verminderten Knorpeldicke (Lane et al. 1977). Veränderungen im Kalzifizierungsgrad und der Dicke des kalzifizierten Knorpels und dem damit verbundenem Vorrücken der Tidemark, sind verbunden mit dem Auftreten von Kollagen-Typ X, MMP13 und dem Transkriptionsfaktor Runx2 (Runt-related transcription factor 2) (Aigner et al. 2004), welcher unter anderem während der Skelettogenese in prähypertrophen und hypertrophen Chondrozyten zu finden ist (siehe Abschnitt 1.4) (Lefebvre und Smits 2005). Kollagen-Typ $X$ ist ebenfalls typisch für hypertrophe Chondrozyten in der kalzifizierten Zone unterhalb der Tidemark. Das zeigt eine Veränderung in der Expression, hin zu den typischen Genen der Chondrozytendifferenzierung und -entwicklung (Sandell und Aigner 2001). Die Chondrozyten in diesem tiefen Bereich des Gelenkknorpels haben das Bestreben, die Defekte zu reparieren und nehmen dabei den hypertrophen Phänotyp an (Wang et al. 2004).

\subsubsection{Therapie}

Aktuelle Behandlungsmethoden der Osteoarthritis führen nicht zu einer vollständigen Regeneration des betroffenen Gelenkes.

Nicht-operative Behandlungsansätze wie schmerzlindernde Medikamente, Physiotherapie oder die Umstellung der Lebensgewohnheiten können die Symptome verringern und die Beweglichkeit verbessern, führen aber zu keiner Heilung (Mankin und Buckwalter 1996).

Die operative Behandlung in Form von Resektionen der betroffenen Gelenke und deren Ersatz durch Implantate aus Polyethylen, Metall oder Keramik kann eine gute Beweglichkeit und Schmerzfreiheit herstellen. Die verwendeten Materialien reichen jedoch nicht an die mechanischen Eigenschaften der natürlichen Gelenkoberfläche heran, wodurch der Erfolg der Behandlung limitiert ist, vor allem bei der Behandlung junger, aktiver Patienten (Buckwalter und Lohmander 1994).

Ein weiterer Therapieansatz ist die Implantation von osteochondrogenen Transplantaten oder autologen Chondrozyten. Hierbei ist ein Erfolg jedoch nur bei lokal begrenzten Läsionen zu erwarten (Steinert et al. 2007). 
Es müssen also Möglichkeiten gefunden werden, die Krankheit nachhaltig zu behandeln und betroffene Gewebe zu regenerieren. Ein Ansatz hierfür ist eine Zell-basierte Knorpelregeneration mit Hilfe von Stammzellen.

\subsection{Chondrogene Progenitor-Zellen (CPC's)}

In späten Stadien der Osteoarthritis sind Chondrogene Progenitor-Zellen im Reparationsgewebe des erkrankten Gelenkknorpels zu finden. Diese CPC's zeigen charakteristische Stammzelleigenschaften und weisen ein hohes chondrogenes Potential auf (Koelling et al. 2009).

Im Rahmen von Untersuchungen der Matrix-Zusammensetzung von osteoarthritisch verändertem Gelenkknorpel wurden Fissuren an der Gelenkoberfläche, die Bildung von Zell-Clustern, sowie Brüche in der Tidemark festgestellt. Zudem wurde gezeigt, dass durch diese Brüche in der Tidemark Blutgefäße in das Knorpelgewebe einwachsen. Bei weiteren Untersuchungen entdeckte man längliche Zellen mit einem weiten endoplasmatischen Retikulum (CPC`s), welche durch diese Tidemark-Brüche in das Knorpelgewebe migrieren (siehe Abbildung 2). Dieses Phänomen konnte in gesundem Knorpel nicht beobachtet werden.

Um zu zeigen, dass sich CPC's von Osteblasten und Chondrozyten unterscheiden, wurden Genexpressionsanalysen durchgeführt. Dafür wurden Osteoblasten aus dem Bereich unter dem osteoarthritischen Knorpeldefekt sowie Chondrozyten aus gesundem Knorpelgewebe gewonnen. Untersucht wurden unter anderem Sox9, ein wichtiger chondrogener Transkriptionsfaktor, Runx2, ein wichtiger osteogener Transkriptionsfaktor (siehe Abschnitt 1.4), sowie Kollagen-Typ I und -Typ II. So weisen Chondrozyten aus gesundem Gelenkknorpel eine hohe Expression von Kollagen-Typ II, eine mittlere Expression von Sox9 und eine niedrige Expression von Kollagen-Typ I und Runx2 auf. Bei den CPC's wurde eine hohe Expression von Kollagen-Typ I und eine mittlere Expression von Sox9 und Runx2 gemessen. In den Osteoblasten wurde eine hohe Expression von Runx2 und Kollagen-Typ I festgestellt (siehe Abbildung 3). Weiterhin wurde durch adipogene, osteogene und chondrogene Differenzierung gezeigt, dass CPC's multipotent sind, was eine charkteristische Eigenschaft von Stammzellen ist. Bei der adipogenen Differenzierung wurden mittels real-time-PCR hohe Level der Lipoproteinlipase (LPL) und von dem Peroxisom-Proliferatoraktivierten Rezeptor y (PPARy), sowie gleichzeitig niedrige Level von Sox9 und Kol- 
lagen-Typ I festgestellt. Bei der osteogenen Differenzierung konnten die Zellen auf Osteocalzin, Ostepontin und Osteonectin positiv getestet werden. Es wurden für Sox9 und Kollagen-Typ II niedrige, für Runx2 und Kollagen-Typ I hohe m-RNA-Level gemessen. Bei der chondrogenen Differenzierung konnten hohe m-RNA-Level für Sox9 und Kollagen-Typ II und niedrige Level für Runx2 und Kollagen-Typ I gemessen werden. Zudem wurden CPC's in eine 3D-Kultur überführt, wobei nach drei Wochen eine Veränderung der Zellen, hin zu einem runderen Chondrozytenähnlichen Phänotyp beobachtet wurde, was gemeinsam mit hohen m-RNA-Leveln für Sox9 und Kollagen-Typ II das ausgeprägte Potential der CPC's zu einer chondrogenen Differenzierung zeigt.

Auch der Einfluss der chondrogenen Mediatoren Transforming-Growth-Factor $\beta 3$ (TGFB3) und dem Bone-Morophogenetic-Protein 6 (BMP6) auf CPC's wurde untersucht, indem man sie mit und ohne diese Zytokine in $3 \mathrm{D}$ kultivierte. Bei den mit TGFB3 und BMP6 kultivierten CPC's wurden höhere m-RNA-Level von Kollagen-Typ II und weniger m-RNA-Level von Kollagen-Typ I und Runx2 gemessen. Sox9 blieb unbeeinflusst.

Weiter konnte dann gezeigt werden, dass der Knockdown von Runx2 mit Hilfe von RNA-Interference (siehe Abschnitt 1.5) in CPC's einen Anstieg der Expression von Sox9, Kollagen-Typ II und Aggrecan zur Folge hat und dadurch das chondrogene Potential der CPC's verstärkt wird. Damit kommt dem Zusammenspiel von Sox9 und Runx2 in diesem Kontext eine wichtige Rolle zu, auch vor dem Hintergrund, dass Runx2 in osteoarthritischem Knorpel vermehrt exprimiert wird (Wang et al. 2004) und dass eine Vektor-vermittelte Überexpression von Sox9 zu einer Wiederherstellung der Knorpelmatrix führen kann (Cucchiarini et al. 2007).

CPC's sind ein vielversprechender Ansatz auf dem Weg zu einer regenerativen Therapie von Knorpelgewebe. 
A

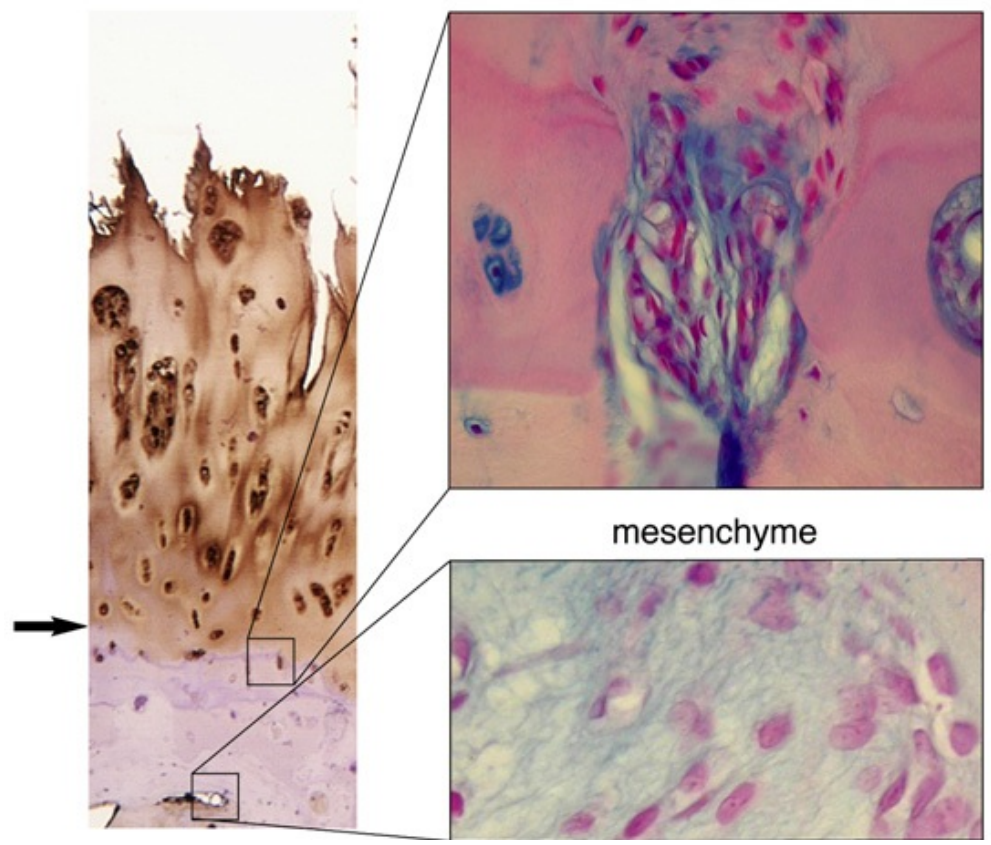

B

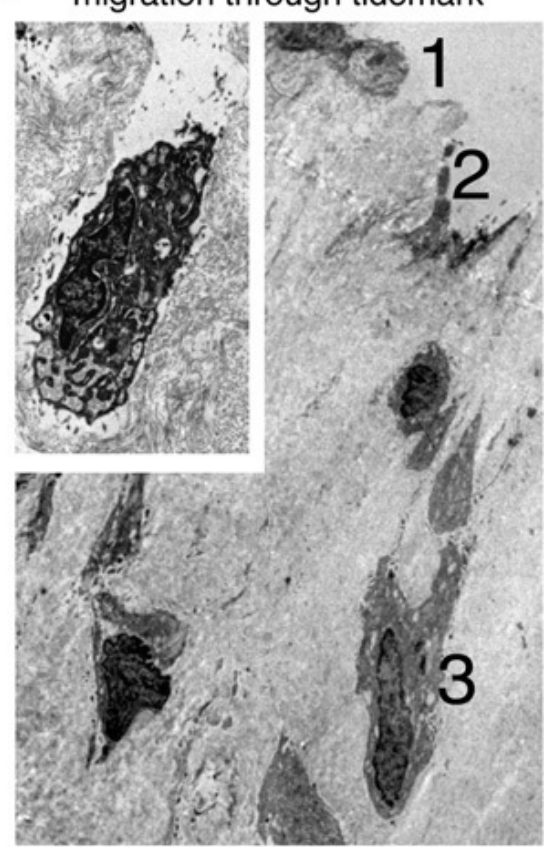

Abbildung 3: (Koelling et al. 2009, S. 325) A: Gewebe von späten Stadien der Osteoarthritis zeigt Fissuren an der Oberfläche, Zell-Cluster-Bildung und Brüche in der Tidemark (Pfeil), welche mit Blutgefäßen gefüllt sind B: Zellen (1-3), welche durch die Tidemark in die Knorpelmatrix migrieren
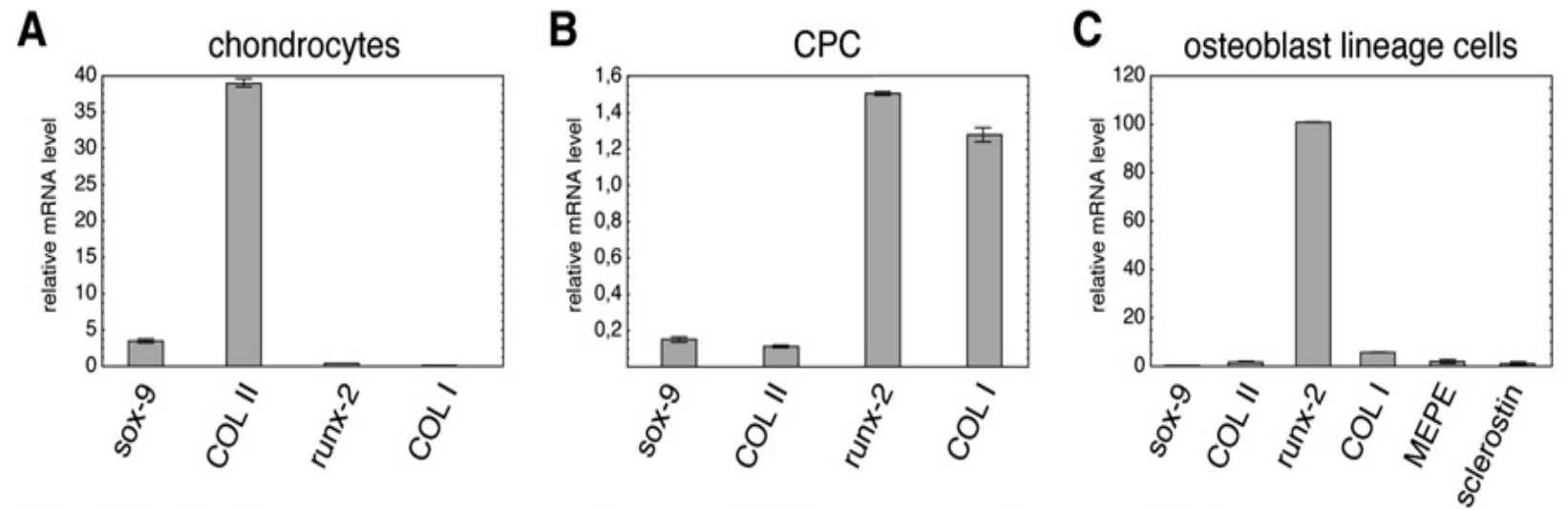

Abbildung 4: (Koelling et al. 2009, S.327) Relative m-RNA-Level von Sox9, Kollagen-Typ II, Runx2 und Kollagen-Typ I für Chondrozyten (A), CPC's (B) und Osteoblasten (C)

\subsection{Runt-related transcription factor 2 (Runx2)}

Der Transkriptionsfaktor Runx2 (Runt-related transcription factor 2) oder Cbfa1 (core binding factor a 1) gehört zu den CBF (Core Binding Factors), einer Gruppe von heterodimeren Transkriptionsfaktoren, welche aus einer $a$ - und einer $\beta$-Untereinheit be- 
stehen. Die a-Untereinheit ist die DNA-Bindende und wird von den drei Genen, Runx1/Cbfa2, Runx2/Cbfa1 und Runx3/Cbfa3 codiert. Diese a-Untereinheiten besitzen alle dieselbe, 128 Aminosäuren lange Domäne, welche aufgrund ihrer Homologie zu dem Drosophila pair-rule-Gen Runt als Runt-Domäne bezeichnet wird (Otto et al. 1997).

Während der embryonalen Entwicklung wird die Differenzierung mesenchymaler Stammzellen in verschiedene Gewebe unter anderem von Transkriptionsfaktoren reguliert. Runx2 wird in mesenchymalen Stammzellen exprimiert und ist ein wichtiger Regulator der Zelldifferenzierung im Rahmen der Knochenentwicklung. Das gilt sowohl für die chondrale als auch für die desmale Ossifikation (Jonason et al. 2009). Die Expression von Runx2 wurde in Vorläuferzellen, welche sich zu Osteoblasten oder zu Chondrozyten entwickeln können, als auch in differenzierten Osteoblasten nachgewiesen (Ducy et al. 1997). Auch in prähypertrophen und hypertrophen Chondrozyten wurde eine Runx2-Expression festgestellt, jedoch nur bis zu einem bestimmten Zeitpunkt der Differenzierung (Inada et al. 1999). In reifen Chondrozyten wurde keine Expression von Runx2 nachgewiesen. Dieses Expressionsmuster deutet auf die entscheidende Rolle von Runx2 innerhalb der Osteoblasten-Differenzierung hin. Zudem wurden in den Promotoren der Gene für Osteocalcin, Kollagen-Typ I und Osteopontin, welche stark in Osteoblasten exprimiert werden, Bindungsstellen für Runx2 nachgewiesen (Ducy et al. 1997).

Tierversuche mit Runx2-Knockout-Mäusen zeigten, dass bei den homozygoten Mäusen keine Ossifikation nachzuweisen war. Die Knorpelentwicklung blieb dabei unbeeinflusst. Die heterozygoten Mäuse zeigten einige skelettale Anomalien, darunter eine Hypoplasie der Claviculae sowie verspätete Ossifikationen der Schädelknochen, was zu einer offenen anterioren und posterioren Fontanelle, sowie zu weiten Suturen führte. Diese phänotypischen Ausbildungen werden auch bei Menschen beobachtet, welche an der genetischen Krankheit Cleidocraniale Dysplasie leiden. Diese ist gekennzeichnet durch eine offene anteriore Fontanelle, Hypo- oder Aplasie der Claviculae, einer weiten Schambeinsymphyse, Zahnüberzahlen und einer kleinen Körperstatur (Otto et al. 1997). Cleidocraniale Dysplasie ist beim Menschen auf dem kurzen Arm des Chromosoms 6p21 lokalisiert (Ramesar et al. 1996), ebenso das Gen für Runx2 (Dixit et al. 2010). 
Das alles lässt auf eine Mutation des Runx2-Gens bei der Cleidocranialen Dysplasie des Menschen schließen.

In osteoarthritisch-verändertem Knorpelgewebe konnte im Vergleich zu gesundem Knorpelgewebe eine erhöhte Expression von Runx2 beobachtet werden. Runx2 konnte zusammen mit der Proteinase MMP13 in Zell-Clustern nachgewiesen werden. MMP13 wird in hypertrophen Chondrozyten vermehrt sezerniert, kann aber auch in arthritisch-verändertem Knorpelgewebe in höherer Konzentration nachgewiesen werden (Wang et al. 2004). Das könnte auf eine Runx2-induzierte Aktivierung der MMP13 hindeuten.

Aufgrund der genannten Erkenntnisse kann Runx2 eine Schlüsselrolle für das Verständnis und eine mögliche Behandlung von Osteoarthritis zukommem.

Es wurde gezeigt, dass sich Runx2 und Sox9 gegenseitig beeinflussen. Dabei hemmt Runx2 die Funktion von Sox9 und umgekehrt (Cheng und Genever 2010).

\subsection{SRY-related HMG-box gene 9 (Sox9)}

Der Transkriptionsfaktor Sox9 gehört zu einer Familie von Proteinen, welche durch eine gemeinsame, DNA-bindende Domäne gekennzeichnet sind. Diese Domäne zeigt eine große Übereinstimmung mit der geschlechtsbestimmenden Region auf dem Y-Chromosom (SRY) von Säugern. Sie wird von einer Variante der HMG-Box codiert, welche erstmals bei den high-mobility-group-Proteinen entdeckt wurde (Lefebvre et al. 1997). Mit der HMG-Domäne kann Sox9 an DNA binden und so als Transkriptionsfaktor wirken (Akiyama et al. 2002).

Sox9 gilt als wichtiger Regulator der Chondrogenese. In mesenchymalen Stammzellen beginnt die Expression von Sox9 schon vor der Kondensation dieser Zellen und definiert sie als Osteo-Chondroprogenitor-Zellen (Akiyama 2005). Auch in Prächondrozyten und Chondroblasten wird Sox9 exprimiert. In prähypertrophen Chondrozyten konnte keine Expression mehr nachgewiesen werden (Lefebvre und Smits 2005).

Mutationen im Sox9-Gen führen zu der Krankheit Campomele Dysplasie, welche durch skelettale Fehlbildungen der durch chondrale Ossifikation entstehenden Knochen charakterisiert ist, was wiederum auf die fundamentale Rolle von Sox9 bei der Knorpelentwicklung hindeutet (Sock et al. 2003). 
Ein Hauptbestandteil der Knorpelmatrix ist Kollagen-Typ II. Schon früh kann während der Chondrozytendifferenzierung eine Expression von Kollagen-Typ II gemessen werden, was diesen Bestandteil der Knorpelmatrix zu einem der ersten und wichtigsten Chondrozytenmarker macht. Lefebvre et al. konnten zeigen, dass zwischen der Expression von Kollagen-Typ II und Sox9 ein direkter Zusammenhang besteht. Dies ist unter anderem dadurch begründet, dass Sox9 an einen Enhancer (Transkriptionsverstärker) des Gens Col2a1 bindet, welches für Kollagen-Typ II codiert (Lefebvre et al. 1997).

Auch Ng. et al. zeigten im Tierversuch mit Mäusen eine gleichzeitige Expression von Kollagen-Typ II und Sox9 während der Knorpelentwicklung. Im Einzelnen wurde die Expression vom Zeitpunkt der mesenchymalem Kondensation über das Stadium der Prächondrozyten und proliferierenden Chondrozyten sowie prähypertrophen Chondrozyten gezeigt. In hypertrophen Chondrozyten wurde keine Expression von Kollagen-Typ II und Sox9 gemessen.

Eine Expression von Sox9 kann während der Embryogenese auch in verschiedenen anderen Zellen beobachtet werden, zum Beispiel in denen der Genitalleiste oder des Herzens. In diesen Zellen wurde keine gleichzeitige Expression von Kollagen-Typ II nachgewiesen ( $\mathrm{Ng}$. et al. 1997). Die Tatsache, dass Sox9 in vielen Zellen exprimiert wird, welche sich untereinander stark unterscheiden, führt zu der Annahme, dass die Expression weiterer Faktoren Einfluss auf die Funktion von Sox9 und die verschiedene Expression in unterschiedlichen Zellen hat. Lefebvre et al. konnten diese Annahme bestätigen und zeigen, dass Sox6 und L-Sox5 (um ca. 300 Basenpaare länger als Sox5), zwei weitere Mitglieder der Sox-Familie, zusammen mit Sox9 während der Chondrogenese exprimiert werden und ebenfalls an bestimmte Stellen des Col2a1Enhancers binden und so mit Sox9 dieses Gen aktivieren. Bei der Transfektion von 10T1/2- und MC615-Zellen mit jeweils L-Sox5, Sox6 oder Sox9 alleine wurde ein geringerer Anstieg der Expression des Col2a1-Gens gemessen als bei der Cotransfektion aller drei Transkriptionsfaktoren zusammen. Hierbei wurde außerdem auch ein Anstieg der Expression von Aggrecan beobachtet, was ebenfalls ein wichtiger Bestandteil der Knorpelmatrix ist. Diese Ergebnisse lassen darauf schließen, dass neben Sox9 auch L-Sox5 und Sox6 eine wichtige Rolle für die Expression knorpelspezifischer Proteine während der Chondrogenese spielen. Jedoch können anscheinend weder L-Sox5, Sox6 noch andere Transkriptionsfaktoren die Funktion von Sox9 erfül- 
len, da eine Mutation im Sox9-Gen zu der schon beschriebenen Campomelen Dysplasie führt (Lefebvre et al. 1998).

\subsection{RNA-Interference}

\subsubsection{Allgemein}

RNA-Interference ist ein Verfahren, um zelleigene Gene abzuschalten, beziehungsweise ihre Expression herunterzuregulieren. Dabei wird nicht das Gen selbst beeinflusst, sondern die m-RNA. Dieses Prinzip ermöglicht die Untersuchung von Genfunktionen und eröffnet neue Therapiemöglichkeiten (Castanotto und Rossi 2009).

Die Entdeckung, dass doppelsträngige RNA komplementäre m-RNA ausschalten kann, wurde mit dem Nobelpreis ausgezeichnet (Fire et al. 1998).

\subsubsection{Mechanismus}

Es findet eine gezielte Ausschaltung, beziehungsweise Herabregulation einzelner Gene statt. Der entscheidende Schritt geschieht während der Proteinbiosynthese, nach der Transkription, auf Ebene der m-RNA.

Der zugrunde liegende Mechanismus beinhaltet verschiedene Schritte: Am Anfang steht eine ds-RNA (doppelsträngige RNA), welche von dem Enzym DICER, einer Ribonuklease-III, in kurze, circa 19 bis 23 Basenpaare lange RNA-Fragmente geteilt wird. Diese RNA-Fragmente werden als si-RNA (small interfering RNA) bezeichnet, und binden an den Enzymkomplex RISC (RNA-induced silencing Complex). Hier wird die si-RNA in ihre Einzelstränge getrennt und der Leitstrang verbleibt in dem RISCKomplex. Die entscheidende Rolle dabei spielt ein Protein der Argonautfamilie, Ago2, welches Bestandteil des RISC-Komplexes ist.

In diesem Zustand ist RISC aktiviert und bindet an die zum Leitstrang komplementäre m-RNA (messenger-RNA). Diese wird durch Ago2, welches eine Domäne mit RNase-Aktivität beeinhaltet, abgebaut. Entscheidend ist, dass die m-RNA und der Leitstrang der si-RNA absolut komplementär sind. So wird die Translation der m-RNA in das von ihr kodierte Protein verhindert (Sashital und Doudna 2010). 


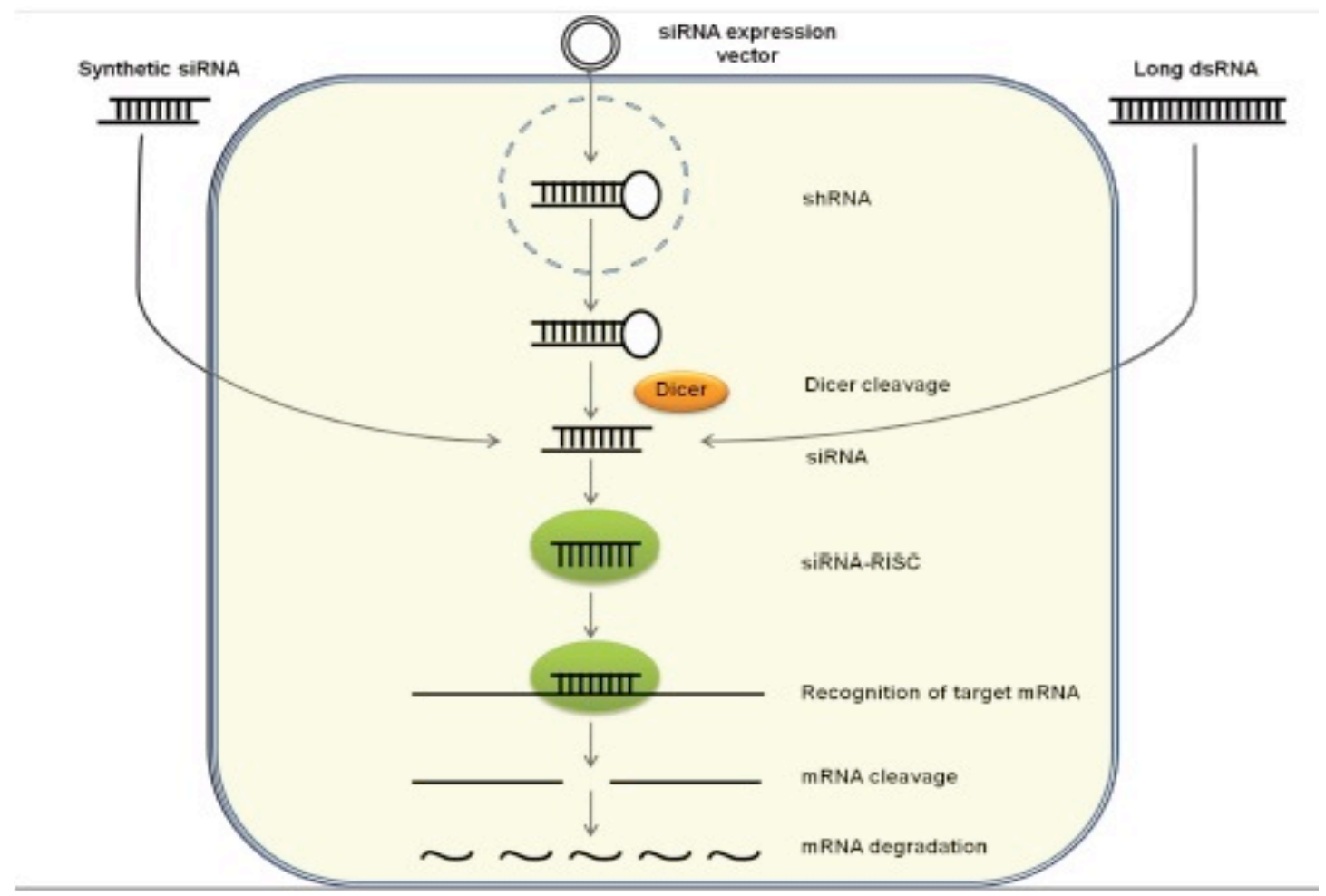

Abbildung 5: (Singhania et al. 2012, S.25) RNA-Interference. Anlagerung von DICER (orange) an ds-RNA, Zerschneiden der ds-RNA, Anlagerung von RISC (grün), Trennung des Doppelstranges durch RISC, Bindung des RISC-Komplexes an komplementäre m-RNA, Abbau der m-RNA

\subsubsection{Verwendung}

Diesen zellulären Mechanismus nutzt man, um bestimmte Gene zu beeinflussen. Dazu wird die, der Nukleotidsequenz der m-RNA des Zielgens entsprechende siRNA von außen in die Zelle eingebracht. Es gibt die Möglichkeit, Zellen mit synthetischer si-RNA direkt zu transfizieren (das heißt die si-RNA in die Zelle einzubringen), wobei die eingebrachte si-RNA direkt in den Enzymkomplex RISC aufgenommen wird. Eine andere Möglichkeit ist, dass die si-RNA in der Ziel-Zelle synthetisiert wird. Dazu transfiziert man die Zelle mit einem Vektor (siehe Abschnitt 1.6), welcher ein Gen für eine sh-RNA (short hairpin-RNA) enthält. Dieses Gen steht unter Polymerase -II- oder Polymerase-III-Promotor-Kontrolle und wird innerhalb der Zellen exprimiert. Die sh-RNA wird dann von DICER in kleine RNA's (21-25 Nukleotide) geteilt. Diese werden dann ebenfalls in RISC aufgenommen. Bei der Transfektion mit einzelnen, synthetischen si-RNA's kann in jedem Fall nur ein transienter, das heißt ein vorübergehender Effekt erzielt werden. Bei den Promotor-exprimierten sh-RNA's ist theoretisch durch eine einzige Transfektion ein stabilerer, länger andauernder 
Gen-Knockdown möglich (Castanotto und Rossi 2009). Ein weiterer Faktor ist, dass DICER vermutlich an der Verbindung der si-RNA mit RISC beteiligt ist, also die aus der sh-RNA entstandenen kleineren RNA's direkt an DICER weitergibt. Dieser Umstand würde bedeuten, dass synthetische si-RNA nicht so effektiv ist, da diese DICER nicht benötigt und direkt in RISC aufgenommen werden soll (Kim et al. 2005). Wie effektiv der Knockdown wird, hängt im Wesentlichen auch vom Design der einzelnen si-RNA`s ab. Dieses kann sich natürlich in der Nukleotidsequenz unterscheiden, aber auch einige andere Faktoren sind zu beachten. Zum Beispiel sollte das 5 '-Ende des Antisinn-Stranges (Leitstrang) eine niedrigere thermodynamische Stabilität haben als das 5'-Ende des Sinn-Stranges, um die Einlagerung in den RISCKomplex zu erleichtern. Um die effektivste zu finden, müssen oft viele verschiedene si-RNA`s gestestet werden (Castanotto und Rossi 2009).

\subsection{Plasmide/Vektoren}

Plasmide sind ringförmige DNA-Moleküle. Es ist möglich eine bestimmte Nukleotidsequenz, welche zum Beispiel ein bestimmtes Protein codiert, in das Plasmid einzubauen. Das Plasmid kann dann in Zellen eingebracht werden und dient so als eine Art Transportvehikel. Solche Plasmide werden in der Molekularbiologie auch als Vektoren bezeichnet.

Diese Vektoren beinhalten eine Reihe, für die experimentelle Verwendung wichtige Elemente wie Schnittstellen für Restriktionsenzyme, Promotor und Antibiotikaresistenzen.

Restriktionsenzyme sind Nucleasen und können DNA sequenzspezifisch zerschneiden. Dies geschieht durch das Spalten von Phosphodiesterbrücken der Nucleinsäure.

Durch die Erkennung bestimmter Sequenzen, welche aus vier bis acht Basen bestehen, schneiden die einzelnen Restriktionsenzyme immer an derselben Stelle. Dabei gibt es Enzyme, welche die DNA glatt in der Mitte ihrer Erkennungssequenz zerschneiden, und solche, die versetzt schneiden, so dass Überhänge, so genannte klebrige Enden, entstehen. Durch diese Überhänge ist es möglich, DNA-Fragmente unterschiedlicher Herkunft, welche durch dasselbe Restriktionsenzym geschnitten wurden, mit der Hilfe einer DNA-Ligase zu verbinden. 
Als Promotor werden DNA-Abschnitte bezeichnet, an welche die DNA-Polymerase zu Beginn der Transkription bindet. Abhängig von der Basensequenz des Promoters, wird ein bestimmter DNA-Abschnitt öfter oder weniger oft transkribiert.

Die Antibiotikaresistenz ist notwendig, um Zellen oder Bakterien, welche mit dem Vektor transfiziert wurden, dass heißt in welche der Vektor eingebracht wurde, von denen zu selektieren, die den Vektor nicht aufgenommen haben. 


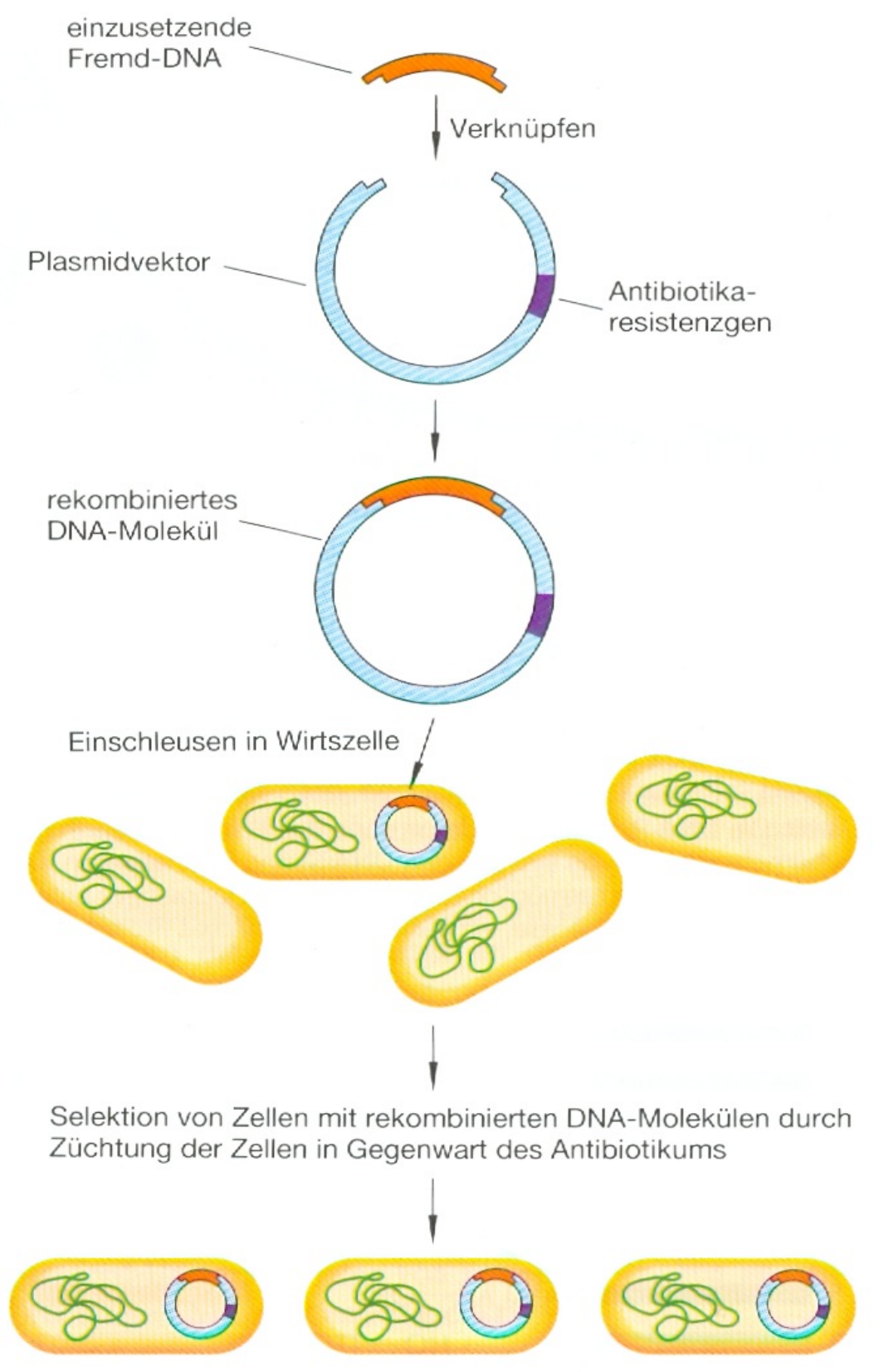

Abbildung 6: (Watson et al. 1993, S.66) Plasmidvektor: Schematische Darstellung der VektorKomponenten sowie der Selektion transfizierter Zellen durch ein Antibiotikum

Der in dieser Arbeit verwendete iLenti-GFP-siRNA-Expression-Vektor (Biocat \#LV016-ABM) enthält zudem ein Gen für das green fluorescenting protein (GFP). Dieses Protein wurde in der Qualle Aequorea victoria entdeckt. Es ist $28 \mathrm{kDa}$ schwer und emittiert unter UV-Licht-Bestrahlung mit einer Wellenlänge von $395 \mathrm{~nm}$ grünes Licht (Wiedenmann et al. 2009). Fluoresziert eine Zelle grün, so ist der Vektor von der Zelle aufgenommen worden. 


\subsection{Frage- und Aufgabenstellung}

Wie unter Punkt 1.3 beschrieben, haben Koelling et al. (2009) mittels si-RNA einen Knockdown von Runx2 in CPC's generiert, welcher allerdings nur von kurzer Dauer war und nicht sicher zu reproduzieren ist. Diese Arbeit hat das Ziel, mit Hilfe eines Vektors, einen länger andauernden Knockdown von Runx2 zu erreichen und dies auf m-RNA- und Proteinebene zu zeigen. Dazu ist es nötig, CPC's mit dem verwendeten Vektor und einer ausreichenden Effizienz zu transfizieren. Nach der Transfektion soll untersucht werden, wie lange der Vektor in den Zellen verbleibt.

Die Fragen sind:

1. Können die CPC`s mit dem iLenti-GFP-siRNA-Expression-Vektor in ausreichender Effizienz transfiziert werden?

2. Wie stabil ist die Transfektion?

3. Ist damit ein längerer Knockdown von Runx2 zu erreichen und sicher zu reproduzieren?

4. Wie effizient ist der Knockdown und wie lange hält er an?

5. Welchen Effekt hat der Knockdown? 


\section{Material und Methoden}

\subsection{Zellkultur}

Immortalisierte Chondrogene Progenitor-Zellen (CPC's) wurden in $75 \mathrm{~cm}^{2}$ großen Zellkulturflaschen (Sarstedt, \# 83.1813.002) kultiviert. In jede Flasche wurde $10 \mathrm{ml}$ Kultivierungsmedium gegeben.

Kultivierungsmedium:

$500 \mathrm{ml}$ DMEM (Gibco \# 21885)

$50 \mathrm{ml}$ FBS (Gibco, \# 10270-106)

5 ml Penicillin/Streptomycin (50000 units/50 mg; PAN Biotech, \# P06-07100)

Die Zellen wurden in einem Zellkulturschrank bei $37^{\circ} \mathrm{C}$ inkubiert. Das Kultivierungsmedium wurde alle zwei Tage gewechselt. Sobald die Flaschen zu etwa 80 Prozent konfluent waren, wurden die Zellen passagiert.

\subsection{Das Plasmid}

\subsubsection{Allgemein}

Es wurde der iLenti-GFP-siRNA-Expression-Vektor (Biocat \# LV016-ABM) verwendet.

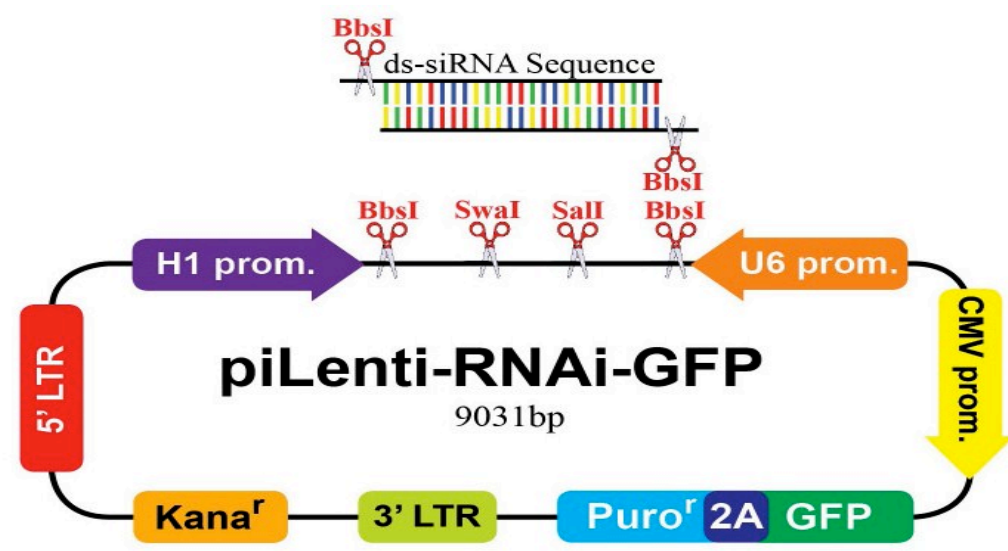

Abbildung 7: iLenti-GFP-siRNA-Expression-Vektor (Biocat \# LV016-ABM) 


\subsection{2 si-RNA}

Es wurden vier dieser Vektoren gekauft, welche sich jeweils durch die Sequenz der sh-RNA bzw. si-RNA unterscheiden. Die Sequenzen der Plasmide 635, 1013 und 1472 wurden von Biocat (Heidelbeg, Deutschland) designed. Das Plasmid 1371 enthält die Sequenz einer si-RNA, welche schon von Koelling et al. (2009) verwendet wurde.

Die vier verschiedenen Sequenzen sind:

635: CCTATCACAGAGCAATTAAAGTTACAGTA

1013: GCATTTCAGGTGCTTCAGAACTGGGCCCT

1371: CAGCACGCTATTAAATGCAAATT

1472: TGGATGAATCTGTTTGGCGACCATATTGA

\subsection{Plasmid-Amplifikation}

\subsubsection{Transformation von Bakterien}

Als Transformation wird die Aufnahme von freier DNA in Bakterienzellen bezeichnet. In dieser Arbeit wurden kompetente DH5a-Bakterien verwendet. Die Bakterien befinden sich in einer Kalzium-Chlorid-Lösung wodurch die Abstoßungskräfte der negativ geladenen DNA und der negativ geladenen Zellmembran verringert werden sollen. Die Lösung wurde auf Eis gestellt und $2 \mu \mathrm{g}$ des Plasmides dazu pipettiert. Nach 10 Minuten Inkubation auf Eis werden die Bakterien 30 Sekunden einem Hitzeschock von $42{ }^{\circ} \mathrm{C}$ ausgesetzt, wodurch kurzzeitig Poren in der Zellmembran entstehen, durch welche die Plasmide in die Bakterienzellen gelangen können. Danach wurden die Bakterien auf einer Agarplatte, mit Kanamycin zur Selektion, ausplattiert und über Nacht bei $37^{\circ} \mathrm{C}$ inkubiert. Am nächsten Tag wurde von der Agarplatte eine Bakterienkolonie mit einer Pipettenspitze "gepickt" und in einen 1-Liter-Erlenmeierkolben, mit 200 ml LB-Medium und Kanamycin gegeben. Das Medium mit dem Antibiotikum und den Bakterien wurde über Nacht bei $37^{\circ} \mathrm{C}$ geschüttelt. 


\subsubsection{Plasmid-Isolation}

Zur Isolation des Plasmids aus den Bakterienzellen wurde das EndoFree-PlasmidMaxi-Kit (Quiagen, \# 12362) verwendet.

Das über Nacht inkubierte LB-Medium mit den Bakterien wurde bei 5000 rpm 15 Minuten abzentrifugiert und das Bakterienpellet in $10 \mathrm{ml}$ P1-Puffer resuspendiert. Anschließend wurden 10 ml P2-Puffer dazu gegeben, sorgfältig gemischt und 5 Minuten bei Raumtemperatur inkubiert. Dann wurden $10 \mathrm{ml}$ P3-Puffer dazugegeben, die gesamte Suspension in eine QIAfilter-Patrone überführt und bei Raumtemperatur 10 Minuten inkubiert. Nach Ablauf der Zeit wurde die Kappe von der Patrone entfernt, der Stempel eingesetzt und das Lysat in ein $50 \mathrm{ml}$ Röhrchen gefiltert. Dazu wurden 2,5 ml ER-Puffer gegeben, gut vermischt und 30 Minuten auf Eis inkubiert. Während dieser Zeit wurde ein QIAGEN-tip-500 äquilibriert, indem $10 \mathrm{ml}$ QBT-Puffer auf die Säule gegeben wurden und gewartet wurde, bis die gesamte Flüssigkeit von alleine durchgeflossen ist. Nach Ablauf der 30 Minuten Inkubation auf Eis wurde das filtrierte Lysat auf die QIAGEN-tip-Säule gegeben und gewartet, bis die Flüssigkeit von alleine durchgeflossen ist. Die QIAGEN-tip-Säule wurde dann zweimal mit $30 \mathrm{ml}$ QC-Puffer gewaschen. Jetzt wird die plasmid-DNA mit $15 \mathrm{ml}$ QN-Puffer in ein endotoxin-freies 30 ml-Röhrchen eluiert. Dann werden 10,5 ml Isopropanol dazu gegeben und die gesamte Lösung 45 Minuten bei 8000 rpm abzentrifugiert. Der Überstand wird vorsichtig weggeschüttet, das plasmid-DNA-Pellet kurz mit $70 \%$-Ethanol gewaschen und dann etwa 10 Minuten getrocknet. Danach wurde das Pellet in 100 $\mu$ I TE-Puffer resuspendiert und die Plasmid-DNA-Konzentration im Photometer (Biophotometer, Eppendorf, Hamburg, Deutschland) gemessen und anschließend auf $1 \mu \mathrm{g}$ pro Mikroliter eingestellt.

\subsection{Transfektion}

\subsubsection{Allgemein}

Die Transfektion beschreibt eine Methode, mit deren Hilfe man Fremd-DNA in Zellen einbringen kann. Grundsätzlich kann man zwischen einer transienten und einer stabilen Transfektion unterscheiden. Bei der transienten Transfektion bleibt die Fremd-DNA nur zeitweilig in der Zielzelle. Durch Abbauprozesse in der Zelle wird 
eine längere Verweildauer verhindert. Im Gegensatz dazu wird bei der stabilen Transfektion die Fremd-DNA in das Wirtsgenom eingebaut und kann so länger in der Ziel-Zelle bleiben.

Es gibt verschiedene Methoden um Zellen zu transfizieren, wobei hier nur auf die verwendete Methode der Nukleofektion eingegangen wird. Die Nukleofektion ist eine Art der Elektroporation, bei der Zelltyp-spezifische Lösungen und elektrische Spannungen verwendet werden. Ausschlaggebend für die Wahl der Methode war die Transfektionseffizienz. Diese lässt sich aus den prozentualen Anteilen der Zellen, welche nach der Elektroporation die eingesetzte Fremd-DNA in sich aufgenommen haben und welche nicht, ableiten.

Bei der Elektroporation wird die Zellmembran der Zielzellen durch elektrische Impulse permeabel gemacht. Dabei baut sich eine transmembrane Spannung auf, die ab einem bestimmten Wert zu hydrophilen Poren in der Zellmembran führt, durch welche die Fremd-DNA in die Zelle eindringen kann. Die Poren bestehen nur wenige Sekunden, da die Membranspannung durch den Ladungsausgleich zusammenbricht. Die Zellen sind während der Transfektion nicht adhärent, sondern befinden sich zusammen mit der Fremd-DNA in Lösung. Bei der Nukleofektion gibt es dabei für viele Zelltypen jeweils unterschiedliche Lösungen.

\subsubsection{Vorbereiten der Zellen}

Die Zellen wurden in der Zellkulturflasche eine Minute mit $5 \mathrm{ml}$ 1X PBS gewaschen. Danach wurde jede Flasche mit $4 \mathrm{ml}$ 1X Trypsin/EDTA für etwa acht Minuten bei $37^{\circ} \mathrm{C}$ im Zellkulturschrank inkubiert. Unter einem Lichtmikroskop wurde kontrolliert, ob sich alle Zellen vom Flaschenboden gelöst haben. In jede Flasche wurden $5 \mathrm{ml}$ Kultivierungsmedium gegeben und die gesamte Flüssigkeit mit den Zellen in ein 15-ml-Röhrchen überführt und bei 1200 rpm 10 Minuten zentrifugiert. Der Überstand wurde vorsichtig abgeschüttet und die Zellen in $1 \mathrm{ml}$ 1X PBS resuspendiert. Die Zellen wurden nun im Zellometer (AutoT4, PeqLab, Erlangen, Deutschland) gezählt. Die gewünschte Menge 1X PBS mit den Zellen wurde in ein $2 \mathrm{ml}$ Eppendorf-Cup überführt und noch mal 10 Minuten bei 1200 rpm zentrifugiert. 


\subsubsection{Transfektions-Protokoll}

DMEM-Zellkulturmedium mit 20\% FBS und 1\% Penicillin/Streptomycin wurde auf $37^{\circ} \mathrm{C}$ erwärmt. Für jede Transfektion wurden aus dem Human-MSC-Nucleofactor-Kit (Lonza \#VVPE-1001) $90 \mu$ l der Nucleofactor-Solution mit $20 \mu$ S Supplement gemischt. In $100 \mu \mathrm{l}$ dieser Lösung wurden die Zellen resuspendiert. Dann wurde 2-4 $\mu \mathrm{g}$ des Plasmids dazu pipettiert und alles in eine Küvette überführt und zur Transfektion in den Nucleofactor (Lonza) gestellt. Es wurde das Programm U-23 gewählt. Unmittelbar nach der Transfektion wurden $500 \mu \mathrm{l}$ des warmen Zellkulturmediums in die Küvette gegeben und danach der gesamte Inhalt in eine $25 \mathrm{~cm}^{2}$-große Zellkulturflasche mit $450 \mathrm{ml}$ des warmen Mediums überführt.

\subsubsection{Kontrolle der Transfektion und Selektionierung}

GFP hat sein Anregungsmaximum bei $395 \mathrm{~nm}$.

Um das Transfektionsergebniss zu kontrollieren und zu dokumentieren, wurde jeweils ein Ausschnitt einer Zellkulturflasche, einmal ohne und einmal mit UV-LichtBestrahlung, unter dem Lichtmikroskop fotografiert (Nikon d90). So können durch das GFP transfizierte von nicht-transfizierten Zellen unterschieden und gezählt werden.

Zur Selektionierung der transfizierten Zellen wurde Kultivierungsmedium mit Puromycin (in einer Konzentration von $5 \mu \mathrm{g} / \mathrm{ml}$ ) auf die Zellen gegeben.

\subsection{RT-PCR}

\subsubsection{Allgemein}

Die RT-PCR (Real-Time-Polymerase-Chain-Reaction) ist eine Methode um die Expression bestimmter Gene einer Zelle quantitativ zu erfassen. Hierfür wird die m-RNA (messenger-DNA) aus Zellen isoliert und mittels einer reversen Transkriptase in eine so genannte c-DNA (copy-DNA) umgeschrieben (siehe "c-DNA-Synthese“). Diese c-DNA wird während des PCR-Programms mithilfe einer hitzestabilen taq-Polymerase des Bakteriums Thermus Aquaticus amplifiziert. Während der 
Synthese wird der Fluoreszenzfarbstoff SYBR-Green in die Doppelstränge der DNA eingebaut.

Die verschidenen Schritte der Amplifikation sind:

\section{Erhitzung auf $95^{\circ} \mathrm{C}$ zur Denaturierung der DNA-Doppelstränge}

2. Annaeling (Anlagerung) der Primer bei einer für den jeweiligen Primer spezifischen Temperatur

3. Synthese der neuen DNA-Doppelstränge mit Hilfe der Taq-Polymerase bei $72^{\circ} \mathrm{C}$ 4. Messung der Fluoreszenz

Diese Schritte werden jeweils 45 mal wiederholt, so dass sich die Menge der spezifischen DNA-Fragmente in jedem Zyklus verdoppelt. Der Zeitpunkt, an dem zum ersten Mal die Hintergrundfluoreszenz überschritten wird, ist durch den ct-Wert (cycle treshold) gekennzeichnet. Dadurch lässt sich eine quantitative Aussage über die eingesetzte Ziel-DNA treffen. Das bedeutet, je grösser die Menge der am Anfang eingesetzten Ziel-DNA war, desto früher wird der ct-Wert erreicht, bzw. je höher der ctWert ist, desto kleiner war die Menge der Anfangs eingesetzten Ziel-DNA.

\subsection{2 m-RNA-Isolation aus Zellen}

Die m-RNA wurde aus den transfizierten Zellen nach den entsprechenden Zeitabständen mit Hilfe des RNeasy-MiniKit’s (Qiagen \#74106) isoliert. Dazu wurde das Kulturmedium aus den Flaschen abgesaugt und die Zellen mit $2 \mathrm{ml}$ PBS eine Minute geschwenkt um Rückstände des Mediums auszuwaschen. Danach wurde $700 \mu \mathrm{l}$ RLT-lysis-Puffer (Qiagen, \#79216) mit $7 \mu \mathrm{l}$ Mercaptoethanol (Sigma-Aldrich, \# 63689) direkt in die Flasche auf die Zellen gegeben und zwei Minuten stehen gelassen. Diese $700 \mu \mathrm{l}$ wurden dann auf einen QIAshredder (\#79056) gegeben und bei $12000 \mathrm{rpm}$ durchzentrifugiert. Der Durchfluss wurde mit $700 \mu \mathrm{l}$ 70\%-Ethanol gut durchmischt, auf eine RNeasy-mini-Säule (\#74106) gegeben, und bei 12000 rpm durchzentrifugiert. Danach wurde der Durchfluss verworfen und die in der Säule zurückgebliebene m-RNA erst mit $700 \mu \mathrm{l}$ RW1-Puffer (Qiagen, \#1015763) und dann mit $500 \mu \mathrm{l}$ RPEPuffer (Qiagen, \#1018013) gewaschen. Anschließend wurde die Säule mit der gewaschenen m-RNA in ein neues Sammelröhrchen gegeben und eine Minute trocken zentrifugiert (12000 rpm). Die Säule wurde dann in ein 1,5 ml Biopur Eppendorf-Cup 
überführt und $50 \mu \mathrm{l}$ RNAse-freies Wasser direkt auf die Membran der Säule pipettiert. Nach fünf Minuten wurde eine Minute bei 12000 rpm zentrifugiert. Der Durchfluss enthält die m-RNA. Die $50 \mu \mathrm{l}$ wurden auf $25 \mu \mathrm{l}$ eingedampft, um eine höhere Konzentration zu erreichen. Die genaue Bestimmung der Konzentration erfolgte daraufhin photometrisch (Biophotometer, Eppendorf, Hamburg, Deutschland). Hierfür wurden $2 \mu \mathrm{l}$ der RNA-Lösung verwendet und bei 260 und $280 \mathrm{~nm}$ gemessen.

\subsection{3 c-DNA-Synthese}

Zur Synthese der c-DNA aus der isolierten m-RNA, wurde das Quanti-Tect-Reverse Transkription-Kit (Qiagen \#205310) verwendet.

Als erstes wurde mit dem gDNA-Wipeout-Buffer die genomische DNA aus den Proben eliminiert. Danach wurde das Enzym reverse-Transkriptase, ein Puffer und Primer zu der Probe gegeben und 15 Minuten bei $42^{\circ} \mathrm{C}$ inkubiert. In diesem Schritt wird die m-RNA in c-DNA umgeschrieben. Es wurde davon ausgegangen, dass die eingesetzte Menge der RNA 1:1 in DNA umgeschrieben wird. Um die reverse-Transkriptase zu inaktivieren, wurden die Proben zum Schluss drei Minuten auf $95^{\circ} \mathrm{C}$ erhitzt und danach mit Wasser auf die gewünschte Konzentration von $1 \mathrm{ng} / \mu \mathrm{l}$ aufgefüllt.

\subsubsection{Verwendete Primer}

\begin{tabular}{|l|l|l|}
\hline Target & Sequenz & Anealing-Temp. \\
\cline { 1 - 2 } Runx2 for. & ttccagaccagcagcactc & $63^{\circ} \mathrm{C}$ \\
\cline { 1 - 2 } Runx2 rev. & cagccagtcaacaccattt & \\
\hline HPRT1 for. & tgacactggcaaaacaatgca & $61^{\circ} \mathrm{C}$ \\
\cline { 1 - 2 } HPRT1 rev. & ggtcctttcaccagcaagct & \\
\hline
\end{tabular}

Tabelle 1: Primer 


\subsubsection{Protokoll der PCR}

Die aus den Zellen isolierte c-DNA wurde für die PCR immer nach demselben Schema vorbereitet:

\begin{tabular}{|l|l|l|}
\hline & \multicolumn{1}{|c|}{ Pro Well } & \multicolumn{1}{|c|}{ Mastermix (3 Well) } \\
\hline c-DNA & $10 \mathrm{ng}$ & $30 \mathrm{ng}$ \\
\hline Primer (forv. + rev.) & je $20 \mathrm{pmol}$ & je $60 \mathrm{pmol}$ \\
\hline $\begin{array}{l}\text { SYBR-Green-Mix (Quiagen \# } \\
204141)\end{array}$ & $5 \mu \mathrm{l}$ & $15 \mu \mathrm{l}$ \\
\hline Wasser & Auffüllen auf $10 \mu \mathrm{l}$ & Auffüllen auf $30 \mu \mathrm{l}$ \\
\hline
\end{tabular}

Tabelle 2: Probenvorbereitung für die PCR

Aus dem Master-Mix wurde dann auf einer 96-Well-Platte jeweils $10 \mu \mathrm{l}$ in ein Well pipettiert, also jeweils drei Wells für eine Probe, und mit optical flat caps (zum Verschluss der 96-Well Platten) verschlossen. Das Pipettieren wurde auf Eis durchgeführt. Danach wurden die Platten einmal kurz bei 1200 rpm abzentrifugiert, um sicher zu sein, dass sich der gesamte Probenansatz gesammelt unten im Well befindet.

Jede PCR wurde dreimal wiederholt, so dass man von jeder Probe am Ende neun Werte hatte.

Mithilfe des Mastercyclers Realplex (Eppendorf, Hamburg, Deutschland) wurde die PCR nach folgendem Protokoll durchgeführt:

\begin{tabular}{|l|l|}
\hline 1. Initiale Denaturierung & 3 Min. bei $95^{\circ} \mathrm{C}$ \\
\hline 2. Denaturierung & 20 Sek. bei $95^{\circ} \mathrm{C}$ \\
\hline 3. Anlagerung der Primer & 20 Sek. bei $53-63^{\circ} \mathrm{C}$ \\
\hline 4. DNA-Synthese & 20 Sek. bei $72^{\circ} \mathrm{C}$ \\
\hline 5. Letzte Synthese & 10 Min. bei $72^{\circ} \mathrm{C}$ \\
\hline
\end{tabular}

Tabelle 3: Protokoll der PCR

Die Schritte 2-4 werden jeweils 45 Mal wiederholt. 


\subsubsection{Statistik}

Die erforderliche Normalisierung der PCR-Daten erfolgte gegen die mRNA von gesunden Knorpelzellen, mithilfe des Housekeeping-Gens HPRT-1, nach Pfaffl (2001). HPRT-1 wurde verwendet, da es in unseren Proben identische ct-Werte aufwies.

\subsection{Western Blot}

\subsubsection{Allgemein}

Der Western Blot ist eine molekularbiologische Methode, bei der Proteine auf einem geeigneten Trägermaterial immobilisiert werden. Mit der Hilfe von mono- oder polyclonalen-Antikörpern können die Proteine nachgewiesen und quantitative Unterschiede beurteilt werden. Als Trägermaterial kommen zum Beispiel PVDF(Polyvinylidenfluorid) oder Nitrozellulose-Membranen zum Einsatz.

Vor dem eigentlichen Blot werden die Proteine mittels SDS-Page (Polyacrylamidgelelektrophorese) nach ihrem Molekulargewicht aufgeteilt. Dazu wird ein Polyacrylamidgel verwendet, welches je nach Größe des zu untersuchenden Proteins, in verschiedenen Konzentrationen verwendet werden kann.

Nachdem sich die Proteine im Gel aufgetrennt haben, wird der eigentliche Blot durchgeführt. Hier werden die Proteine durch das Anlegen einer zum Gel und der Membran senkrechten Spannung in die Membran überführt, wo Sie aufgrund hydrophober Wechselwirkungen haften bleiben. Die Anordnung der Proteine in dem Gel bleibt auch in der Membran erhalten.

Nachdem die Proteine auf die Membran übertragen wurden, können Sie mittels Farblösungen, wie zum Beispiel Coomassie-Blue, unspezifisch angefärbt und sichtbar gemacht werden. Dadurch ist es möglich zu überprüfen, ob und in welcher Menge Proteine in die Membran übertragen wurden. Die Membran wird dann wieder entfärbt und man kann mit Hilfe von Antikörpern die Immunreaktion durchführen. Hierbei wird der Antikörper an das entsprechende Protein gebunden und dann mit einem Detektionssystem sichtbar gemacht. 


\subsection{Probenvorbereitung}

Die transfizierten chondrogenen progenitor Zellen wurden in der Zellkulturflasche eine Minute mit $2 \mathrm{ml}$ 1X PBS gespült um Rückstände des Kultivierungsmediums zu entfernen. Danach wurde $2 \mathrm{ml}$ 1X Trypsin/EDTA in jede Flasche gegeben und etwa acht Minuten bei $37^{\circ} \mathrm{C}$ im Brutschrank inkubiert. Sobald sich alle Zellen vom Flaschenboden gelöst haben, was unter dem Mikroskop überprüft wurde, wird in jede Flasche $3 \mathrm{ml}$ Kultivierungsmedium pipettiert. Dadurch wird das Trypsin/EDTA inaktiviert. Die Flüssigkeit aus den Flaschen wird in ein $10 \mathrm{ml}$-Röhrchen überführt und 10 Minuten bei 1200 rpm zentrifugiert. Der Überstand muss vorsichtig abgeschüttet, und das Zellpellet in $1 \mathrm{ml}$ 1X PBS resuspendiert werden. Hiervon wurden $20 \mu \mathrm{l}$ zum Zählen der Zellen entnommen. Nach dem Zählen wird die für 10X2 Zellen entsprechende Menge PBS in ein $2 \mathrm{ml}$ Eppendorf-Cup überführt und 10 Minuten bei 1200 rpm zentrifugiert. Der Überstand wird vorsichtig abpipettiert und das Zellpellet in $40 \mu \mathrm{l} 3 \mathrm{X}$ SDS-Probenpuffer mit $100 \mu$ l beta-Mercaptoethanol resuspendiert.

3X SDS-Probenpuffer:

$0.3 \mathrm{M}$ Tris $-3,6 \mathrm{~g}$

$9 \% \mathrm{SDS}-9 \mathrm{~g}$

$22.5 \%$ Glycerin - 22,5 g

Eine Spatelspitze Bromphenolblau

Vor der Zugabe von SDS mit HCl auf pH 6,7 ad $100 \mathrm{ml}$ mit Wasser

Nun werden die Proben für drei Minuten auf $95^{\circ} \mathrm{C}$ erhitzt. Dadurch denaturieren die Proteine, wobei das beta-Mercaptoethanol Disulfidbrücken spaltet. Die noch warmen Proben können nun auf das Gel gegeben werden.

\subsubsection{Natriumdodecylsulfat-Polyacrylamidgelelektrophorese (SDS-PAGE)}

Nachdem die Proben auf das Polyacrylamidgel pipettiert wurden, legt man eine Spannung an und die Proteine laufen durch das Gel. Dabei wirkt das Gel wie ein Netz, welches je nach Konzentration, weitere oder engere Maschen hat. Dadurch wandern die kleinen Proteine schneller und weiter als die größeren. 
Das Gel besteht aus zwei Phasen, dem Sammelgel und dem Trenngel. Zur Herstellung werden folgende Komponenten benötigt:

\section{Sammelgelpuffer}

$0,5 \mathrm{M}$ Tris $\rightarrow 15.1 \mathrm{~g}$

mit $\mathrm{HCl}$ auf $\mathrm{pH}$ 6,8 ad $250 \mathrm{ml}$ mit Wasser

\section{Trenngelpuffer}

$1,5 \mathrm{M}$ Tris $\rightarrow 45,4 \mathrm{~g}$

mit $\mathrm{HCl}$ auf $\mathrm{pH} 8,9$ ad $250 \mathrm{ml}$ mit Wasser

$10 \% \operatorname{SDS}$

$100 \mathrm{~g}$ SDS ad $1000 \mathrm{ml}$ mit Wasser

Acrylamid

$10 \%$ Amonium peroxodisulfat (APS) $\rightarrow 1 \mathrm{~g} / 10 \mathrm{ml}$ Wasser

Für das Sammelgel (5\%) werden die folgenden Komponenten gemischt:

$\begin{array}{ll}\text { Sammelgelpuffer } & 1,25 \mathrm{ml} \\ 10 \% \text { SDS } & 50 \mu \mathrm{l} \\ \text { TEMED } & 5 \mu \mathrm{l} \\ \text { Acrylamid } & 0,8 \mathrm{ml} \\ \mathrm{H}_{2} \mathrm{O} & 2,7 \mathrm{ml} \\ 10 \% \text { APS } & 0,2 \mathrm{ml}\end{array}$

Für das Trenngel (10\%) werden die folgenden Komponenten gemischt:

Trenngelpuffer $\quad 1,4 \mathrm{ml}$

$10 \%$ SDS $\quad 55 \mu \mathrm{l}$ 
TEMED $\quad 5 \mu \mathrm{l}$

Acrylamid $\quad 1,85 \mathrm{ml}$

$\mathrm{H}_{2} \mathrm{O} \quad 2,0 \mathrm{ml}$

$10 \%$ APS $\quad 0,25 \mathrm{ml}$

Bevor man mit dem Gießen des Gels beginnt, werden die Glasplatten mit 100\%Ethanol gereinigt. Die Glasplatten werden dann gegeneinander mit einer Gummidichtung abgedichtet und mit Klammern fixiert. Mit einem Lineal werden sechs Zentimeter von dem unteren Rand der Glasplatten abgemessen und markiert. Nun wird zuerst das Trenngel zusammen pipettiert und, nachdem es gut gemischt wurde, bis zur Markierung zwischen die beiden Glasplatten gegossen. Das Gel wird sofort mit Ethanol überschichtet, damit beim polymerisieren eine glatte Kannte entsteht. Während das Trenngel polymerisiert, wird das Sammelgel zusammen pipettiert. Der Ethanol wird abgeschüttet und das Sammelgel auf das Trenngel gegeben. In das noch flüssige Sammelgel wird ein Kamm gesteckt, wodurch sich Geltaschen für die Proben bilden.

Die Elektrophorese wird in einem Nachbau der Biometra-Elektrophoresekammer durchgeführt. Dazu wird 1X Laufpuffer benötigt.

\section{Laufpuffer:}

$0,25 \mathrm{M}$ Tris $\rightarrow 30,3 \mathrm{~g}$

1,9 M Glycine $\rightarrow 142,6 \mathrm{~g}$

$0,5 \%$ SDS $\rightarrow 50 \mathrm{ml} 10 \%$ SDS

auffüllen auf $1000 \mathrm{ml}$ mit Wasser

Zuerst wird die untere Elektrophoresekammer mit Laufpuffer gefüllt. Die Gummidichtung wird zwischen den Glasplatten entfernt und das Gel in den Laufpuffer gestellt, ohne das sich Blasen unter dem Gel bilden. Das Gel wird fixiert und auch die obere Elektrophoresekammer wird mit Laufpuffer befüllt.

Nun können die Proben in die Geltaschen pipettiert werden, wobei $35 \mu$ für eine Tasche verwendet wurden. In eine Tasche wurden $5 \mu$ l einer Proteinleiter (Fermentas \#SM0671) pipettiert. Im Sammelgel werden die Proben bei 10 bis $15 \mathrm{~mA}$ bis zur Trenngelkannte konzentriert und dann bei 20 bis $25 \mathrm{~mA}$ im Trenngel aufgetrennt. 


\subsubsection{Der Blot}

Nachdem sich die Proteine in dem Gel aufgetrennt haben, werden sie in einem TankBlot-System auf eine PVDF-Membran übertragen. Dazu wird in dem mit Transferpuffer gefüllten Tank, eine Spannung senkrecht zur Membran angelegt. Diese Methode wird als Nassblot bezeichnet.

Der Transferpuffer wird folgendermaßen hergestellt:

\section{Transferpuffer}

$25 \mathrm{mM}$ Tris $\rightarrow 6,05 \mathrm{~g}$

$192 \mathrm{mM}$ Glycine $\rightarrow 28,8 \mathrm{~g}$

$20 \%(\mathrm{v} / \mathrm{v})$ Methanol $\rightarrow 400 \mathrm{ml}$

mit $\mathrm{H}_{2} \mathrm{O}$ auf 2000 ml auffüllen, pH 8,3

Für den Blot werden eine PVDF-Membran und sechs Filterpapiere zurechtgeschnitten, so dass die Filterpapiere die Membran etwas überragen. Die PVDF-Membran wird 15 Sekunden in Methanol gelegt und dann zwei Minuten in Wasser. Danach werden die Schwämme der Blotkassette, die Filterpapiere und die PVDF-Membran in kaltem Transferpuffer mindestens 15 Minuten eingelegt. Der Zusammenbau der Kassette erfolgt in einer mit Transferpuffer gefüllten Schale. Dazu werden zuerst drei Filterpapiere auf einen Schwamm gelegt und das Gel darauf platziert. Die Membran wird dann luftblasenfrei auf das Gel gelegt und mit den restlichen Filterpapieren und dem Schwamm bedeckt. Die Kassette wird mit zwei Gummibändern fixiert und in den Blottank gestellt. Dabei ist darauf zu achten, dass die Membran zur Anode und das Gel zur Katode orientiert sind. Der Tank wird komplett mit Transferpuffer befüllt. Die Proteine wandern dann in 90 Minuten bei 350 mA von dem Gel in die Membran. Dabei muss der Tank mit Wasser gekühlt werden und auf einem Rührtisch stehen, damit während des Blots eine gleichmäßige lonenkonzentration gewährleistet ist. 


\subsubsection{Proteinfärbung auf PVDF-Membran}

Für die unspezifische Färbung der Proteine auf der Membran werden folgende Komponenten benötigt:

\section{Coomassie-Blau}

0,1\% Coomassie brilliant blue R250 Powder (Serva \#1752b) $\rightarrow 0,1 \mathrm{~g}$

\section{Entfärber-eins}

$5 \%$ Methanol $\rightarrow 50 \mathrm{ml}$

$7 \%$ Essigsäure $\rightarrow 7 \mathrm{ml}$

mit Wasser auf $100 \mathrm{ml}$ auffüllen

\section{Entfärber-zwei}

$90 \%$ Methanol $\rightarrow 90 \mathrm{ml}$

$10 \%$ Essigsäure $\rightarrow 10 \mathrm{ml}$

Die Membran wird zwei Minuten in die Coomassie-Lösung gelegt und etwas geschwenkt. Danach legt man die Membran zwei bis fünf Minuten in den Entfärbereins und dann in den Entfärber-zwei, bis die Hintergrundfärbung weg ist und die Proteinbanden deutlich sichtbar werden.

Die Membran wird jetzt eingescannt.

Bevor mit der Immunreaktion fortgefahren wird, muss die Membran zwei mal fünf Minuten in TBS-T gewaschen werden

\subsubsection{Immunreaktion}

Für die Immunreaktion werden folgende Lösungen vorbereitet: 
10XTBS

$200 \mathrm{mM}$ Tris $\rightarrow 24,2 \mathrm{~g}$

$1,5 \mathrm{M} \mathrm{NaCl} \rightarrow 87,6 \mathrm{~g}$

mit $\mathrm{H}_{2} \mathrm{O}$ auf $1000 \mathrm{ml}$ auffüllen, $\mathrm{pH} 7,4$

TBS-T

$100 \mathrm{ml}$ 10X TBS

$0,05 \%$ Tween $\rightarrow 0,5 \mathrm{~g}$

mit $\mathrm{H}_{2} \mathrm{O}$ auf $1000 \mathrm{ml}$ auffüllen

Blocklösung

$5 \%$ Milchpulver in TBS-T

Verdünnungslösung für Antikörper

Primärer Antikörper: 5\% Milchpulver in TBS-T

Sekundärer Antikörper: 5\% Milchpulver in TBS-T

Antikörper

\begin{tabular}{|l|l|}
\hline Antikörper & Verdünnung \\
\hline $\begin{array}{l}\text { Anti-Runx2: Monoclonaler Antikörper } \\
\text { (Millipore, Nr.: PSO1450380) }\end{array}$ & $1: 1000$ \\
\hline $\begin{array}{l}\text { Anti-Sox9: Polyklonaler Antikörper } \\
\text { (Acris, Cat.-Nr.: APO6583PU-N) }\end{array}$ & $1: 1000$ \\
\hline $\begin{array}{l}\text { Anti-a-Tubulin: Monoclonaler Antikörper } \\
\text { (Sigma-Aldrich, Nr.: T6199) }\end{array}$ & $1: 1000$ \\
\hline $\begin{array}{l}\text { Anti-Rabbit IgG: Polyclonaler Antikörper } \\
\text { (Dako, Nr.:ZO196) }\end{array}$ & $1: 100.000$ \\
\hline $\begin{array}{l}\text { Anti-Mouse IgG: Polyklonaler Antikörper } \\
\text { (Nr.: D0314) }\end{array}$ & $1: 40.000$ \\
\hline
\end{tabular}

Tabelle 4: Antikörper 
Alle folgenden Schritte werden auf einer Wippe durchgeführt. Dabei befindet sich die Membran in einer kleinen Schale.

Im ersten Schritt werden die unspezifischen Bindungsstellen auf der Membran geblockt. Dazu legt man die Membran eine Stunde bei Raumtemperatur in die Blocklösung. Danach wird der primäre Antikörper mit der Antikörperverdünnungslösung auf die Membran gegeben und zwei Stunden bei Raumtemperatur oder über Nacht im Kühlraum geschwenkt. Die Verdünnung hängt von dem jeweiligen Antikörper ab. Für den Runx2-Antikörper wurde eine Verdünnung von 1:1000 gewählt. Bevor man den sekundären Antikörper auf die Membran gibt, muss diese fünf mal fünf Minuten mit TBS-T gewaschen werden. Der sekundäre Antikörper wurde 1:40.000 verdünnt und dann für ein bis zwei Stunden bei Raumtemperatur auf die Membran gegeben. Danach wird die Membran fünf mal fünf Minuten mit TBS-T gewaschen. Im nächsten Schritt können die Antikörper mit dem ECL-Plus-Detection-System von Amersham (\# RPN2106) nachgewiesen werden. Dazu mischt man die Detektionslösung $A$ und $B$ in einem Verhältnis von 40:1 und inkubiert damit die Membran für fünf Minuten. Jetzt kann die Membran zwischen eine Klarsichtfolie und dann in eine Röntgenfilmkassette gelegt werden.

Die folgenden Schritte müssen in einer Dunkelkammer durchgeführt werden. Hier wird Fotopapier (Amersham Hyperfilm ECL, \# 28-9068-35) in die Röntgenfilmkassette gelegt und für fünf Minuten belichtet. Danach kann der Film entwickelt und fixiert werden. 


\section{Ergebnisse}

\subsection{Transfektion}

Um die Effizienz der Transfektion zu überprüfen und zu dokumentieren wurden die Zellen unter dem Lichtmikroskop fotografiert. Dabei wurde jeweils ein Foto der Zellen ohne und eines mit UV-Licht-Bestrahlung (Wellenlänge $395 \mathrm{~nm}$ ) gemacht. Alle Zellen die das Plasmid aufgenommen haben, exprimieren das GFP und fluoreszieren deshalb unter dem UV-Licht grün.

Die Transfektion der CPC's wurde zu Beginn mit verschiedenen Anzahlen von Zellen durchgeführt. Dabei wurde deutlich, dass mit weniger als 400.000 Zellen keine ausreichende Effizienz zu erreichen war.

A

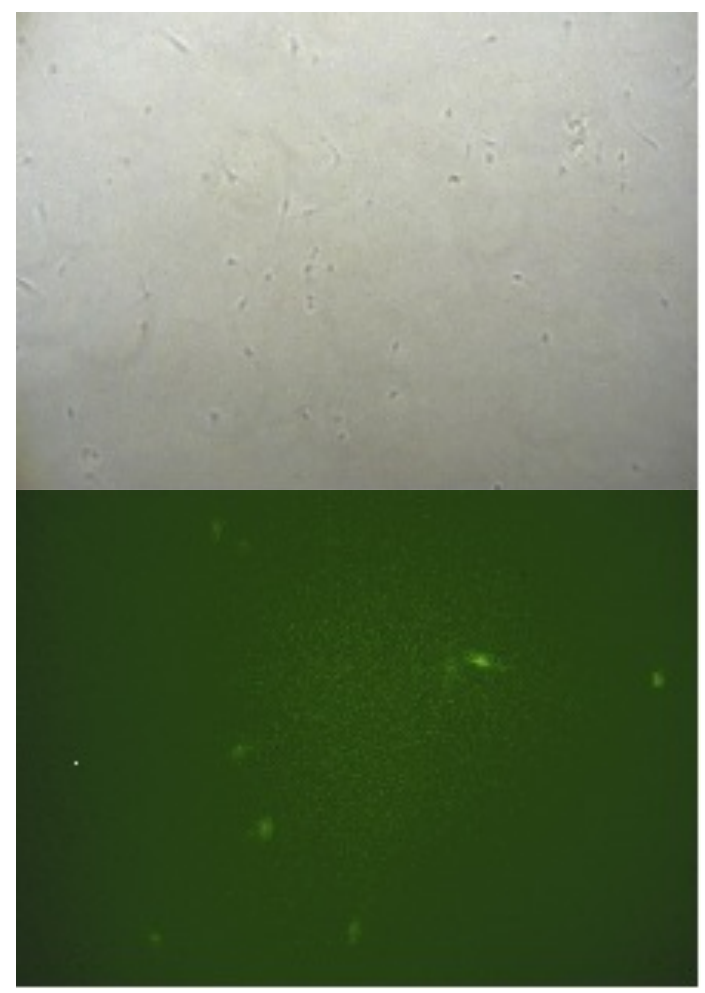

B

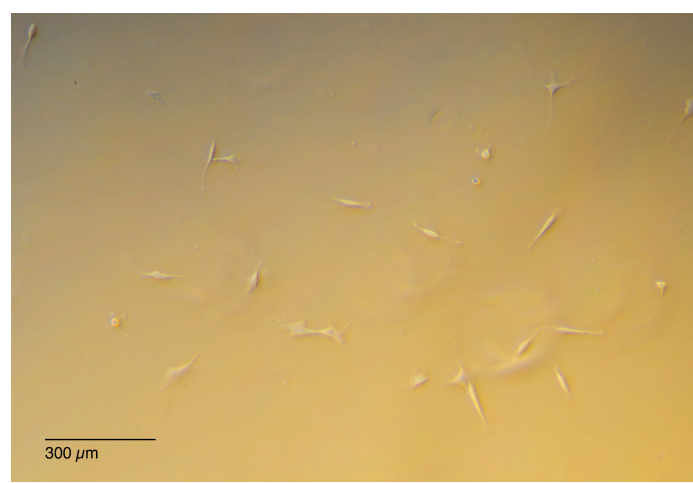

Abbildung 8: Erste Versuche: CPC's in einer $75 \mathrm{~cm}^{2}$-Zellkulturilasche 24 Stunden nach Transfektion von 250.000 Zellen (A),CPC`s mit Maßstabsbalken (B)

Weiterhin wurde die Größe der Zellkılturflaschen variiert, in welche die CPC's nach der Transfektion ausgesät wurden. Bei einer zu transfizierenden Zellzahl von 
400.000 bis 700.000 zeigte sich, dass Zellkulturflaschen mit einer Grösse von $25 \mathrm{~cm}^{2}$ am besten geeignet sind.

Auch wurden die Programme U23 und U17 des Amaxa Nucleofactors verglichen. Nach Herstellerangaben führt das Programm U23 zu einer höheren Effizienz und U17 zu einer höheren Überlebensrate der Zellen. Diese Angaben konnten in unseren Versuchen bestätigt werden. Bei dem vom Hersteller vorgegebenen Programm U17 war die Effizienz wesentlich geringer als bei U23, so dass weiterhin nur noch das vom Hersteller vorgegebene Programm U23 verwendet wurde. Dabei starben ungefähr 40 Prozent der Zellen durch die Transfektion.

Um die Überlebensrate der Zellen nach der Transfektion zu steigern, wurden die Zellen die ersten 24 Stunden nach der Transfektion in Zellkultivierungsmedium mit 20 Prozent FCS gegeben.

Durch eine Zellzahl von 400.000 bis 700.000 CPC's pro Transfektion, sowie eine engere Lage der Zellen in der $25 \mathrm{~cm}^{2}$-Flasche, konnten effizientere Ergebnisse erzielt werden.

A

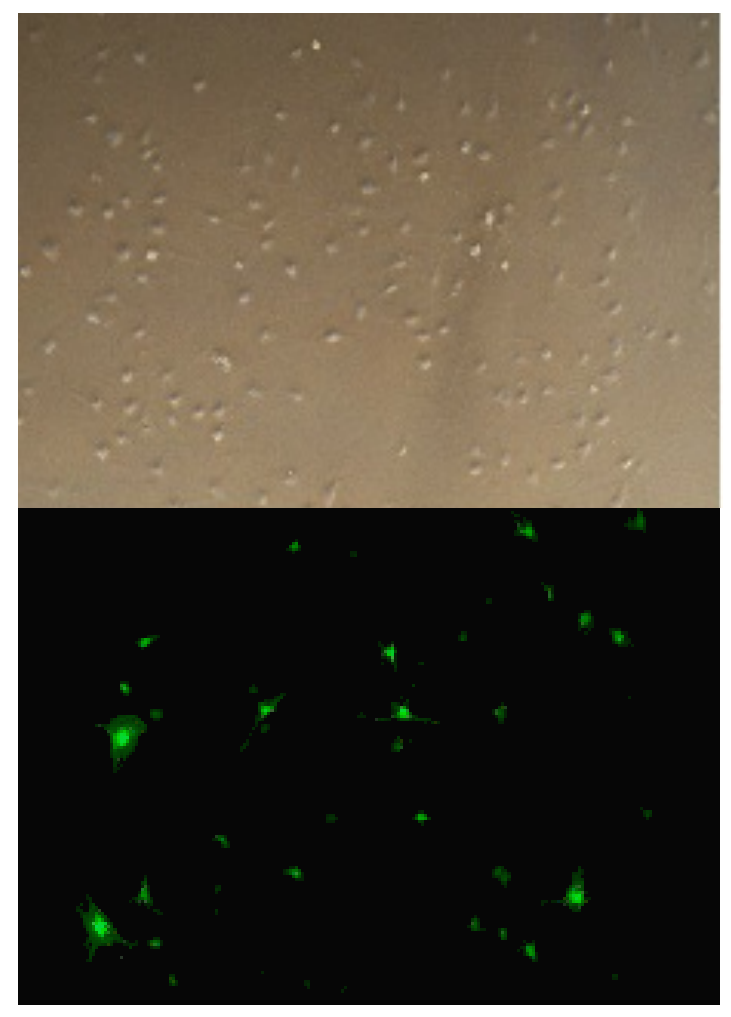

$\mathrm{B}$

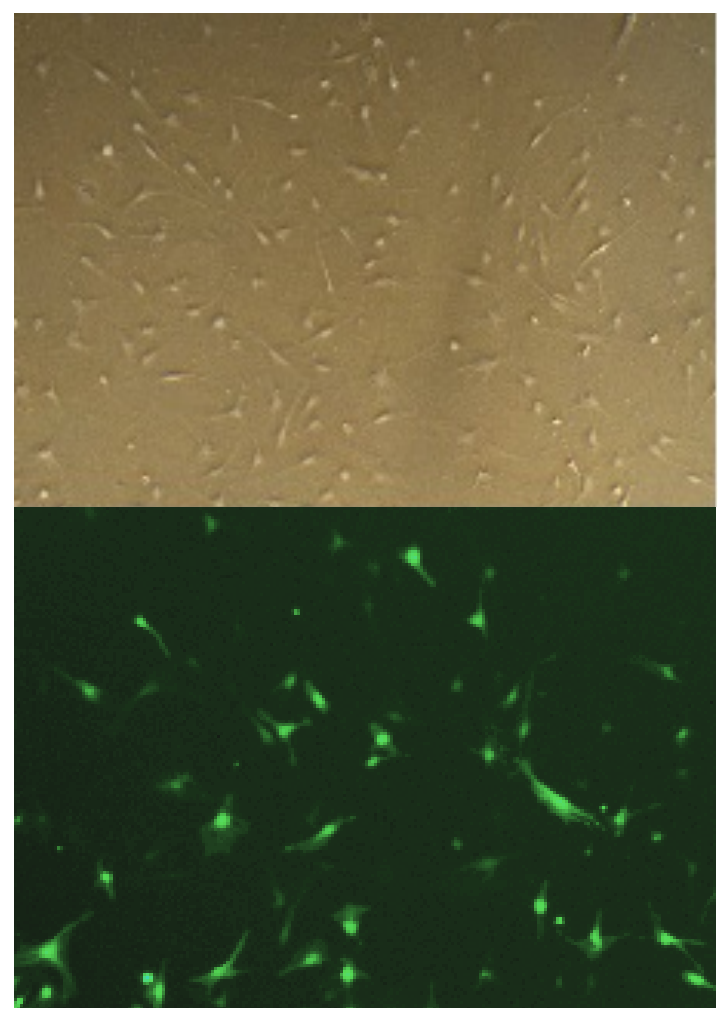

Abbildung 9: CPC's 12 (A) und 24 (B) Stunden nach der Transfektion von 600.000 Zellen in $25 \mathrm{~cm}^{2}$ Zellkulturflaschen 
Es wurde mithilfe von Fotos dokumentiert, wie lange das Plasmid in den Zellen verbleibt, beziehungsweise, wie lange fluoreszierende Zellen zu sehen sind. Dabei konnte beobachtet werden, dass die Anzahl der fluoreszierenden Zellen, sowie auch die Intensität der Fluoreszenz stetig abnahmen und nach etwa 14 Tagen keine fluoreszierenden Zellen mehr zu sehen waren. 
A

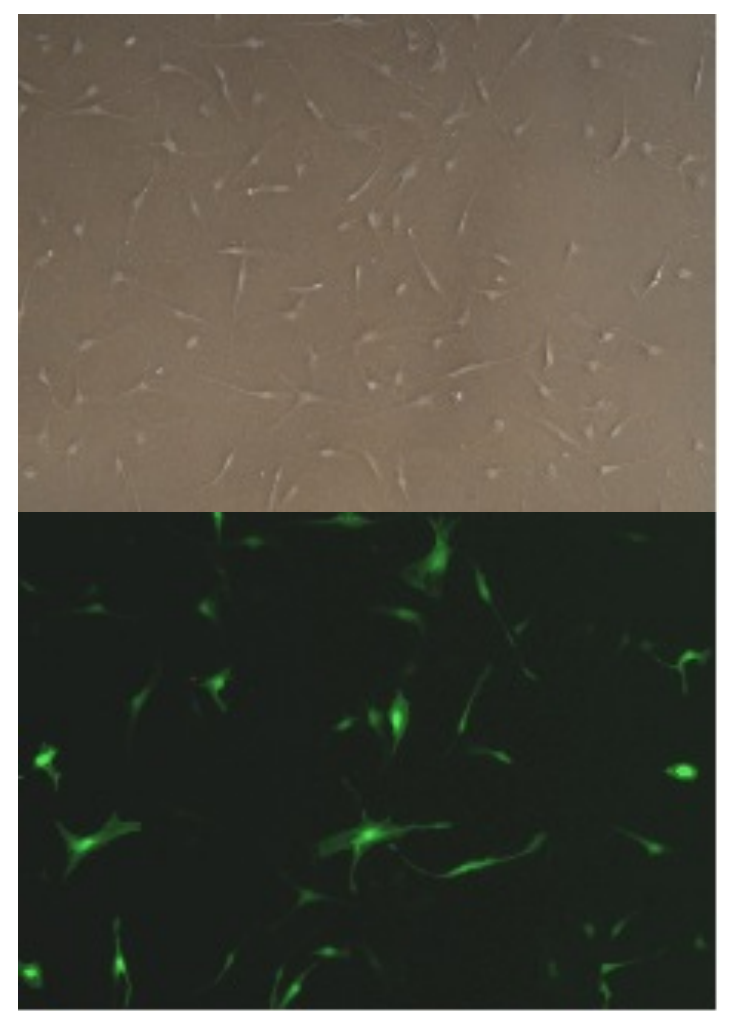

$\mathrm{C}$

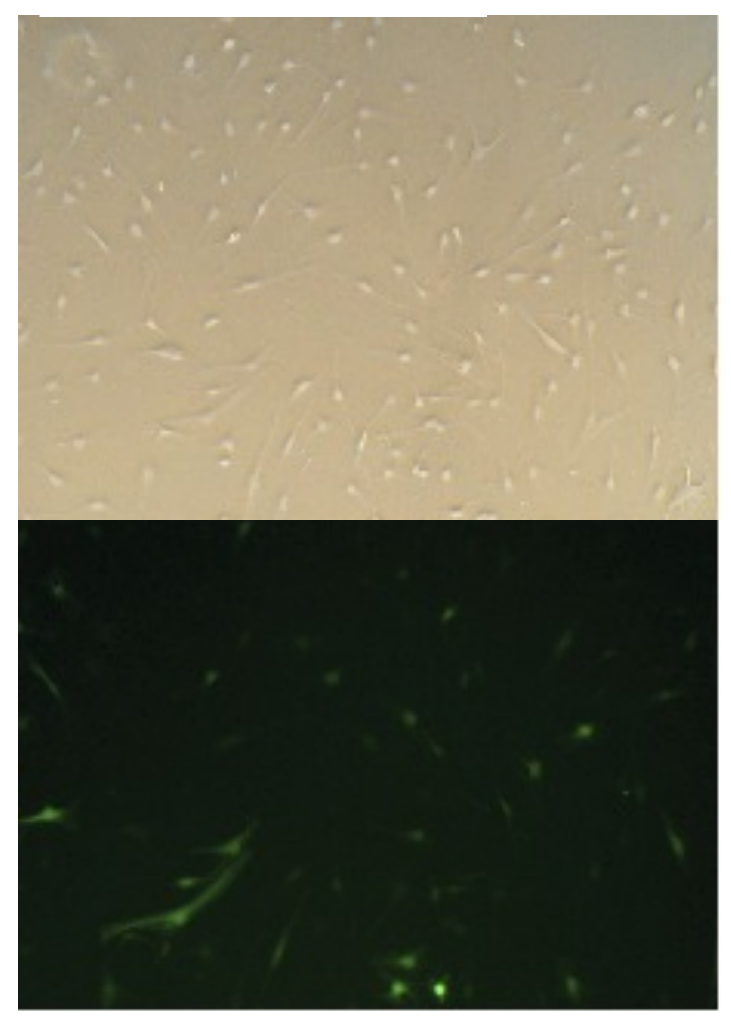

$\mathrm{D}$
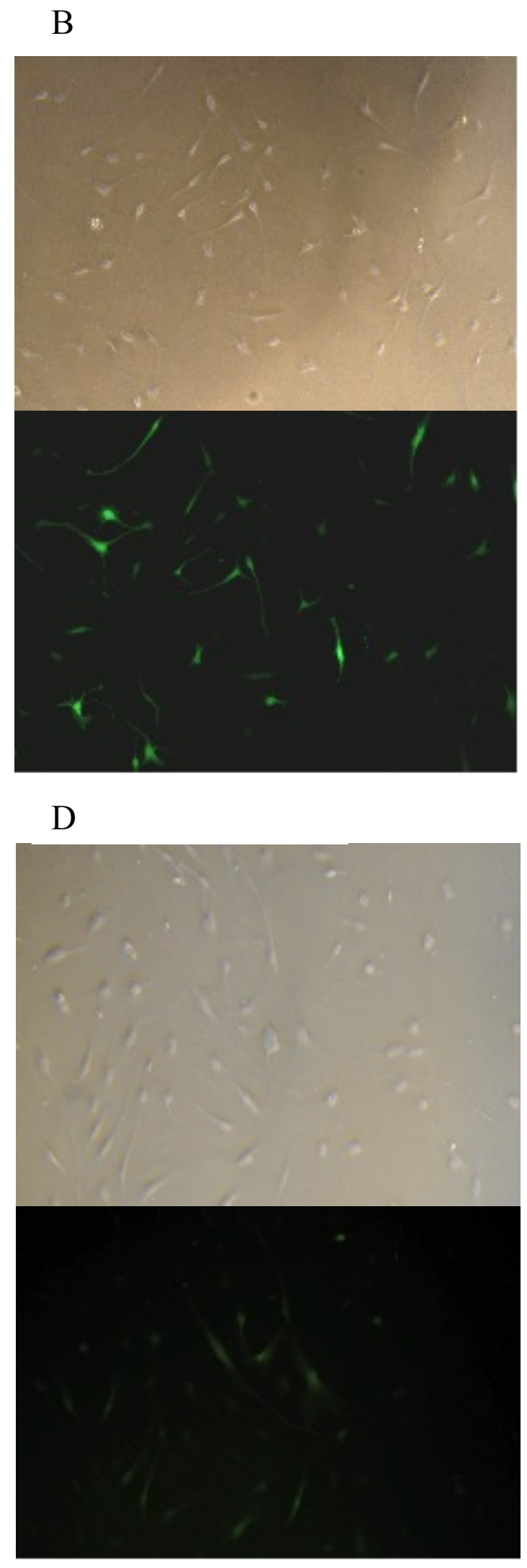

Abbildung 10: CPC's 72 Stunden (A), 5 Tage (B), 7 Tage (C) und 13 Tage (D) nach der Transfektion 
Auch die Intensität der Fluoreszenz variiert zwischen den einzelnen Zellen. Wie man auf den Fotos sieht, leuchten einige Zellen stark grün und andere schwächer. Um die Zellen zu selektionieren wurden sie mit Puromycin behandelt.

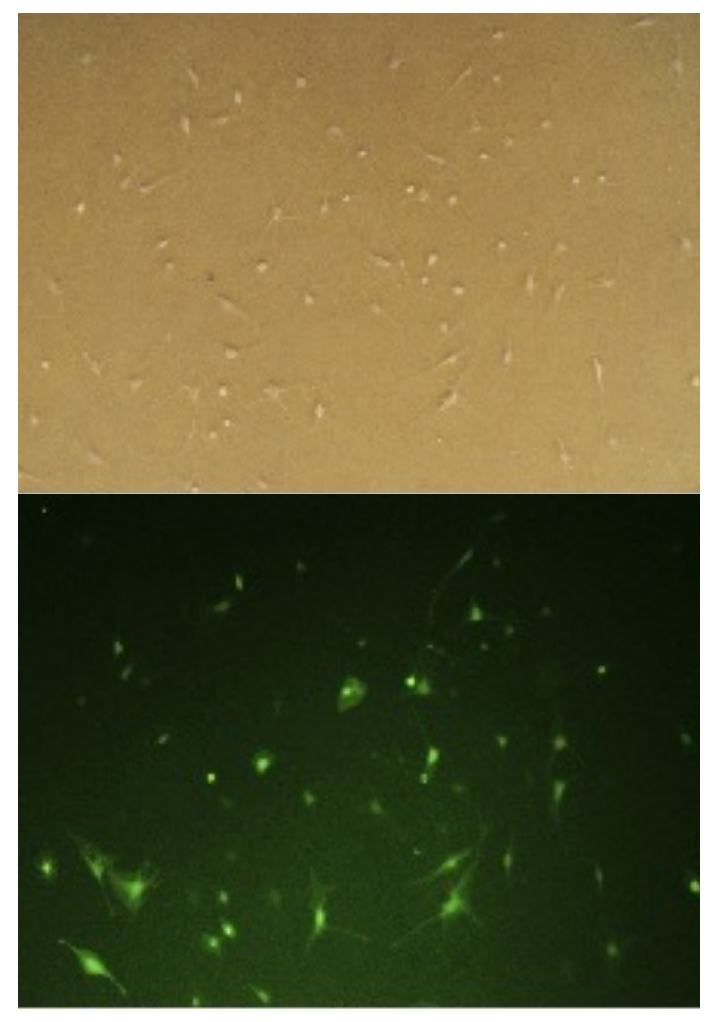

Abbildung 11: Transfizierte CPC`s 48 Stunden nach Transfektion und mit Puromycin selektioniert

Durch die Selektionierung konnte ein Anteil von über 90 Prozent transfizierter Zellen erreicht werden. 14 Tage nach der Transfektion waren alle mit Puromycin behandelten Zellen gestorben. 


\subsection{PCR}

Zum Vergleich der vier Plasmide mit den unterschiedlichen si-RNA-Sequenzen für Runx2, wurde 72 Stunden nach der Transfektion der Zellen die m-RNA isoliert und eine PCR durchgeführt, um einen möglichen Knockdown von Runx2 auf Ebene der m-RNA zu messen. Alle ct-Werte wurden nach Pfaffl normalisiert (Pfaffl 2001).

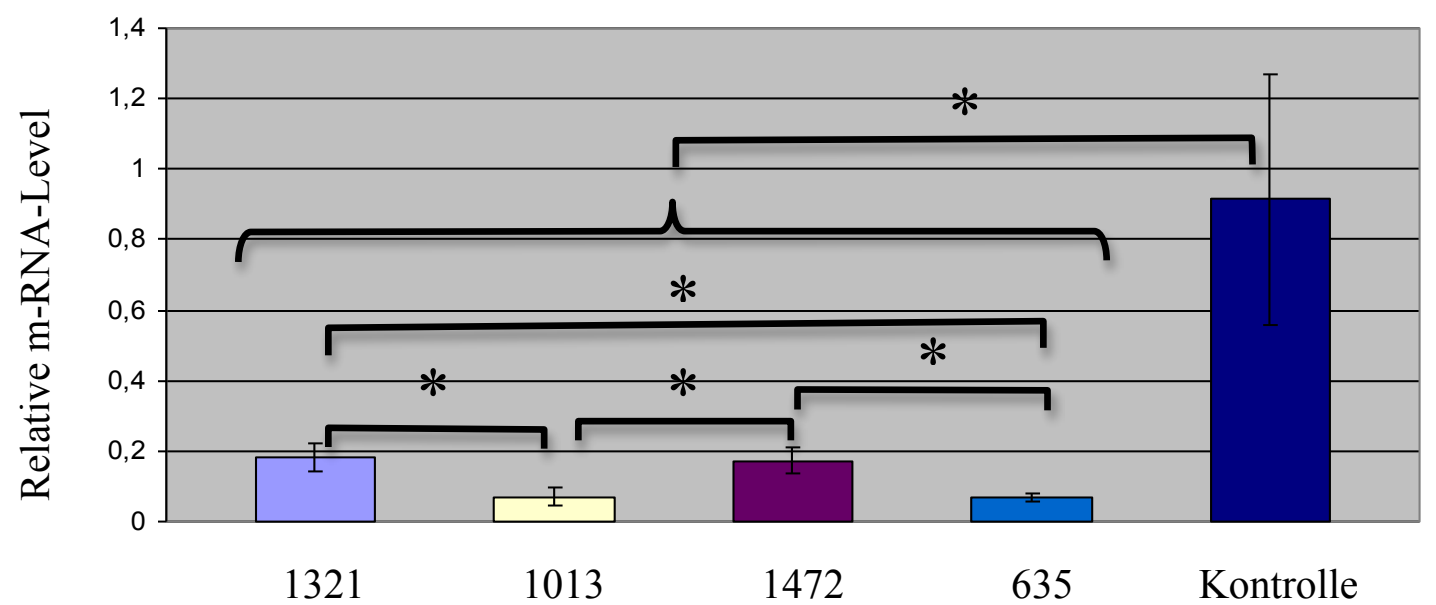

Abbildung 12: Säulendiagramm der relativen m-RNA-Level von Runx2 in CPC's nach Transfektion der Zellen mit den vier verschiedenen Plasmiden und von nicht-transfizierten CPC`s als Kontrolle. Die Ergebnisse sind Mittelwerte von drei getrennten Experimenten, die Fehlerbalken beschreiben die Standardabweichung. ${ }^{*}=$ Signifikant $(p<0,05)$

Die Ergebnisse der PCR zeigen bei allen transfizierten Zellen ein geringeres m-RNALevel für Runx2 als die Kontrolle. Im Vergleich der vier Plasmide 1321, 1013, 1472 und 635 sind die Unterschiede gering. Für die weiteren Versuche wurde das Plasmid 635 verwendet. 
Um die relativen m-RNA-Level von transfizierten CPC's nach verschiedenen Zeitintervallen zu messen, wurde 12 bis 96 Stunden nach der Transfektion die m-RNA aus den Zellen isoliert und eine PCR durchgeführt. Als Kontrolle wurde wieder die m-RNA nicht-transfizierter CPC's verwendet.

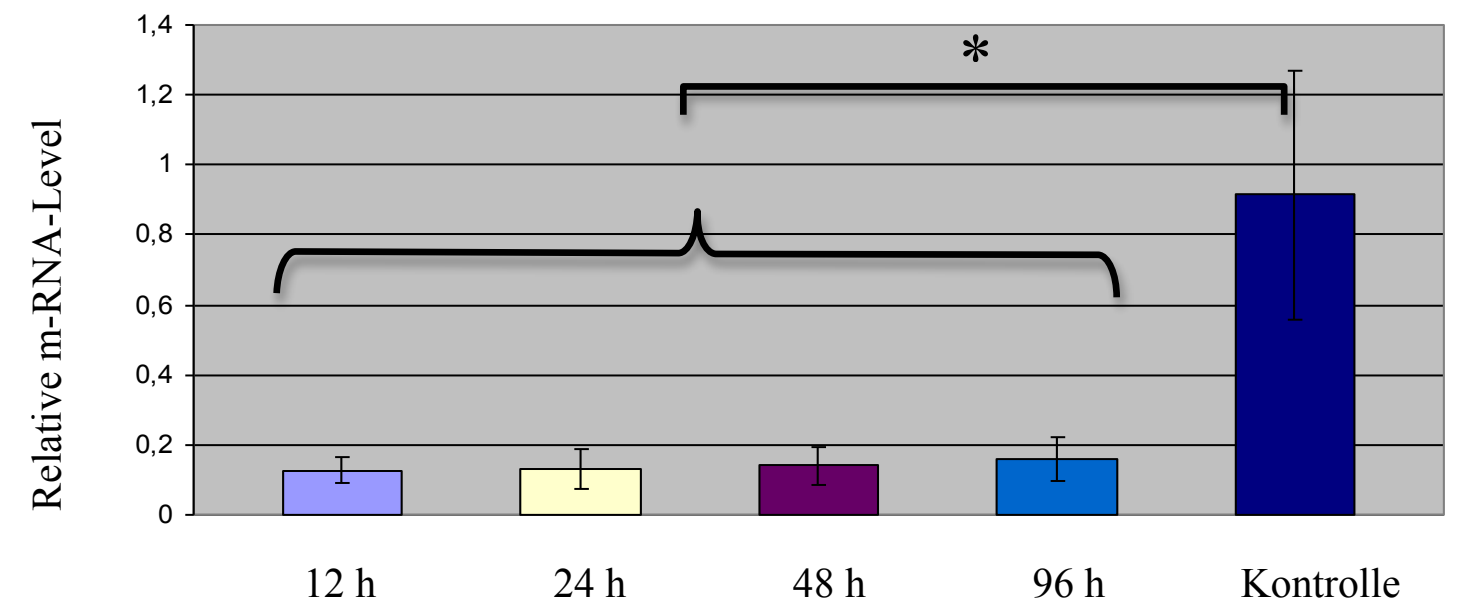

Abbildung 13: Relative m-RNA-Level für Runx2, der mit dem Plasmid 635 transfizierten CPC's nach 12 bis 96 Stunden, und nicht-transfizierter CPC's als Kontrolle. Die Ergebnisse sind Mittelwerte von drei getrennten Experimenten, die Fehlerbalken beschreiben die Standardabweichung. ${ }^{*}=$ Signifikant $(p<0,05)$

$\mathrm{Zu}$ allen Zeiten weisen die transfizierten Zellen ein geringeres m-RNA-Level für Runx2 auf als die nicht-transfizierten. Das m-RNA-Level für Runx2 steigt von 12 bis 96 Stunden leicht an. 


\subsection{Western Blot}

Zur Überprüfung des möglichen Knockdowns von Runx2 auf Proteinebene wurden Western Blots durchgeführt. Die Zellen wurden 12, 24, 48, und 96 Stunden nach der Transfektion geerntet und auf das Gel aufgetragen. Als Positivkontrolle wurden CPC's ohne den iLenti-GFP-siRNA-Expression-Vektor aufgetragen.

A

$72 \mathrm{kDa}$

$55 \mathrm{kDa}$
B

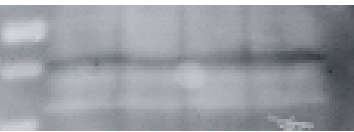

$\mathrm{C}$

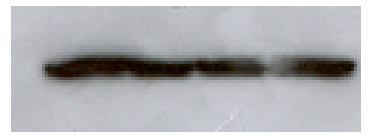

Abbildung 14: Kontrolle: Western Blot mit nicht-transfizierten CPC's. Coomassie-Färbung (A), Fotofilm mit Runx2-Banden bei ca. 57 kDa (B) und Fotofilm mit alpha-Tubulin-Banden bei ca. 55 kDa (C)

A

$72 \mathrm{kDa}$
$55 \mathrm{kDa}$

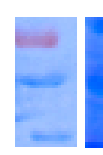

B

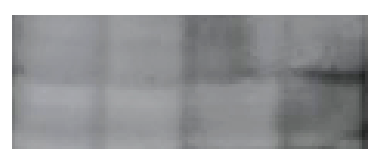

$\begin{array}{llll}12 & 24 & 48 & 96\end{array}$
$\mathrm{C}$

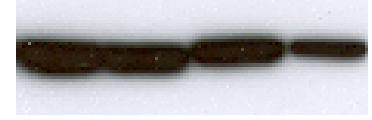

Abbildung 15: Western Blot mit CPCs 12, 24, 48 und 96 Stunden nach Transfektion mit dem iLentiGFP-siRNA-Expression-Vektor. Coomassie-Färbung (A), Fotofilm mit Runx2-Banden (B) und Fotofilm mit alpha-Tubulin-Banden (C)

Abbildung 15 zeigt die Ergebnisse des ersten Western Blots. Anhand der Coomassie-Färbung und der alpha-Tubulin-Kontrolle ist zu sehen, dass unterschiedliche Zellzahlen aufgetragen wurden. Der Grund dafür ist, dass nach 48 und 96 Stunden schon mehr der transfizierten Zellen gestorben waren als nach 12 und 24 Stunden. In diesem Fall führten unterschiedliche Zellzahlen, beziehungsweise Proteinmengen nicht zu einem weniger aussagekräftigen Ergebnis, sondern das Gegenteil ist der Fall. Obwohl bei der 12 und der 24 Stunden-Probe mehr Gesamtprotein-Menge vorhanden ist als bei der 96 Stunden-Probe, zeigt sich in der Immunreaktion gegen 
Runx2 bei 96 Stunden eine stärkere Bande. Bei 12 und 24 Stunden sind die Banden gleichmäßig schwach, bei 48 Stunden etwas stärker.

Bei einem zweiten Versuch wurden für jede Probe mehrere Transfektionen durchgeführt um die Zellzahl für den Western Blot angleichen zu können, so dass gleiche Proteinmengen aufgetragen werden konnten.

A

$72 \mathrm{kDa}$
$55 \mathrm{kDa}$
B

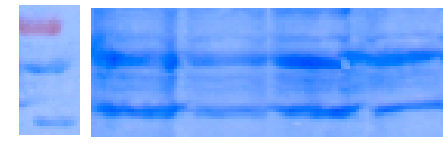

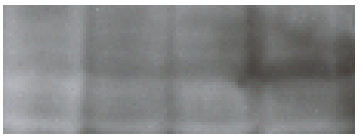

$\begin{array}{llll}12 & 24 & 48 & 96\end{array}$

C
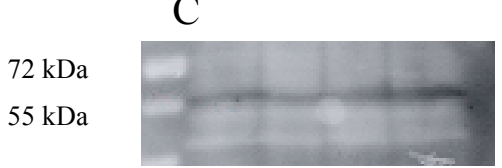

$\mathrm{C}$

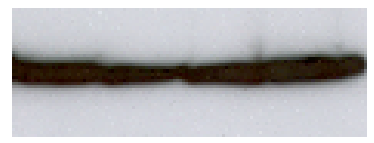

Abbildung16: Western Blot mit CPC`s 12, 24, 48 und 96 Stunden nach Transfektion mit dem iLentiGFP-siRNA-Expression-Vektor. Coomassie-Färbung (A), Fotofilm mit Runx2-Banden (B) Fotofilm mit alpha-Tubulin-Banden (C) und Fotofilm mit Runx2-Banden nicht-transfizierter CPC`s als Kontrolle

In Abbildung 16 ist anhand der Coomassie-Färbung und der alpha-Tubulin-Kontrolle zu sehen, dass gleich viel Gesamtprotein für jede Probe aufgetragen wurde. Auch hier ist zu erkennen, dass die Bande bei 96 Stunden am stärksten ist, bei 12 Stunden am schwächsten und bei 24 und 48 Stunden etwa gleich stark ist.

Ein dritter Western Blot wurde nach demselben Schema durchgeführt. Bei der Immunreaktion mit dem Runx2-Antikörper und der Filmentwicklung kam es zu Artefakten (siehe die schwarze Bande bei der 12 Stunden-Probe und die weißen Stellen bei der 24 Stunden-Probe).Trotzdem ist zu erkennen, dass bei 12 und 24 Stunden eine schwache Bande, bei 48 Stunden eine etwas stärkere Bande und bei 96 Stunden die stärkste Bande zu sehen ist. Zudem wurde hier eine Kontrolle mit auf dasselbe Gel aufgetragen (K). 
A

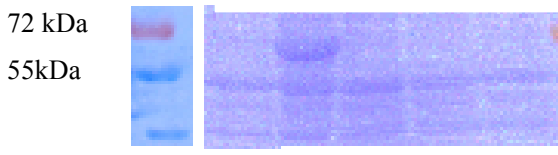

$\mathrm{B}$

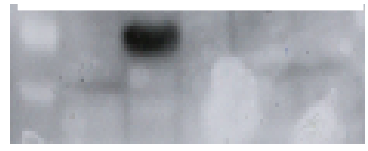

K $\quad 12 \quad 24 \quad 48 \quad 96$
$\mathrm{C}$

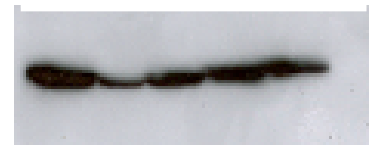

Abbildung 17: Western Blot mit CPC's 12, 24, 48 und 96 Stunden nach Transfektion mit dem iLentiGFP-siRNA-Expression-Vektor und CPC's ohne den Vektor als Kontrolle (K). Coomassie-Färbung (A), Fotofilm mit Runx2-Banden (B) und Fotofilm mit alpha-Tubulin-Banden (C)

Sox9 ist ein Transkriptionsfaktor, welcher während der Chondrogenese und auch in ausgereiften Chondrozyten exprimiert wird. In osteoarthritischen Chondrozyten ist die Expression von Sox9 geringer (Salminen et al. 2001). Es wurde ein Zusammenhang zwischen der Expression von Sox9 und Runx2 beschrieben (Koelling et al. 2009).

Um die Auswirkungen des Runx2-Knockdowns auf Sox9 zu untersuchen wurde die Immunreaktion mit einem Sox9-Antikörper durchgeführt (Abb. 18, D).

A

$72 \mathrm{kDa}$
$55 \mathrm{kDa}$
B

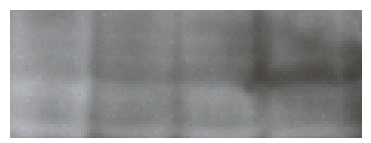

$\mathrm{D}$

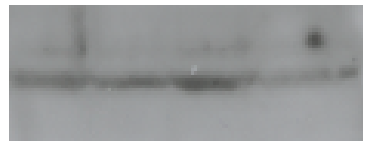

$12 \quad 24 \quad 48 \quad 96$
$\mathrm{C}$

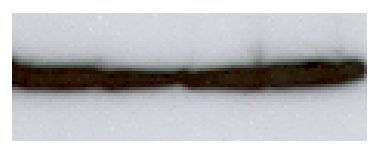

Abbildung 18: Western Blot mit CPC's 12, 24, 48 und 96 Stunden nach Transfektion mit dem iLentiGFP-siRNA-Expression-Vektor. Coomassie-Färbung (A), Fotofilm mit Runx2-Banden (B), Fotofilm mit alpha-Tubulin-Banden (C) und Fotofilm mit Sox9-Banden (D)

Bei den 12, 24 und 48 Stunden-Proben sind stärkere Banden zu erkennen als bei der 96 Stunden-Probe. 


\section{Diskussion}

\subsection{Allgemein}

In beginnenden osteoarthritischen Läsionen innerhalb des Knorpelgewebes ist durch die fehlende Vaskularisierung das Regenerationspotential sehr gering. Hat der Defekt den subchondralen Knochen erreicht, kommt es zur Ruptur von Blutgefäßen und der Bildung von fibrillärem Knorpelgewebe. Dieses Reparationsgewebe hat eine andere Zusammensetzung als der hyaline Knorpel und ist diesem mechanisch unterlegen.

Es muss also das Ziel sein, eine Therapie zu finden, durch welche es zu einer Regeneration von Gelenkknorpel mit hyalinem Knorpelgewebe kommt. Eine Möglichkeit ist dabei die Gentherapie. Hierbei gibt es verschiedene Ansatzmöglichkeiten, wie zum Beispiel die Mitglieder der TGF- $\beta$-Superfamilie oder die Matrixkomponenten des hyalinen Knorpels (Longo et al. 2012).

In dieser Arbeit geht es um einen Ansatz im Bereich der Transkriptionsfaktoren, speziell Runx2 und Sox9, und einen effektiven Transportweg eines Vektors in CPC's, Zellen mit Stammzelleigenschaften und hohem chondrogenem Potential.

\subsection{Effizienz und Stabilität der Transfektion}

Ein Ziel dieser Arbeit war, eine effiziente und leicht reproduzierbare Methode zu finden, um CPC's mit dem iLenti-GFP-siRNA-Expression-Vektor zu tranzfizieren. Diese Zellen könnten Kandidaten sein, für eine zellbasierte Regeneration von osteoarthritischem Knorpelgewebe. Runx2 könnte hierbei, als ein wichtiger Transkriptionsfaktor der Osteo- und Chondrogenese, eine Schlüsselrolle spielen.

Allgemein kommt Stammzellen in der Zukunft eine wichtige Rolle beim Behandeln von Krankheiten zu. Dabei ist der effiziente Gentransport ein entscheidender Schritt auf dem Weg für ein besseres Verständnis der Zellbiologie und einer gezielten Therapie (Kobayashi et al. 2005).

Die effiziente Transfektion der CPC's mit dem iLenti-GFP-siRNA-Expression-Vektor kann eine Grundlage für weitere Untersuchungen einzelner Gene und deren Funktionen in diesen Zellen bilden. Die in dieser Arbeit verwendete Methode der Nukle- 
ofektion gilt als effizient und ist auch für Zelltypen geeignet, welche schwer zu transfizieren sind (Lakshmipathy et al. 2004).

Die in der Literatur beschriebenen Transfektionseffizienzen für Stammzellen mittels Nukleofektion liegen bei 60 bis 90 Prozent (Lakshmipathy et al. 2004; Haleem-Smith et al. 2005; Kobayashi et al. 2005). In dieser Arbeit konnte bei der Transfektion von CPC's mit Hilfe der Nukleofektion ebenfalls eine Effizienz von 60-90 Prozent erreicht werden.

Bei der Nukleofektion der CPC's musste für eine gute Effizienz eine starke Toxizität der Methode in Kauf genommen werden. Durch die Verwendung von Zellkultivierungsmedium mit 20 statt 10 Prozent FCS unmittelbar nach der Transfektion, konnte die Überlebensrate der Zellen jedoch gesteigert, und so auch die Effizienz verbessert werden. Dieser Effekt wurde auch schon von Haleem-Smith et al. beschrieben (Haleem-Smith et al. 2005).

Durch die Verwendung unterschiedlich großer Zellkulturflaschen, in welche die Zellen nach der Transfektion gegeben wurden, konnte festgestellt werden, dass eine engere Lage der Zellen zu einander einen positiven Einfluss auf die Transfektionseffizienz, beziehungsweise auf die Überlebensrate der Zellen hat.

Um die Effizienz der Transfektion beurteilen zu können, wurde das Greenfluorescenting-Protein (GFP) verwendet. Fluoreszierende Proteine werden in einer Vielzahl von Experimenten als Marker genutzt. In einem Lichtmikroskop mit UV-Licht der Wellenlänge $395 \mathrm{~nm}$ ist GFP ungefähr sechseinhalb Stunden nach der Transfektion, in lebenden Zellen, das erste mal zu sehen (Wiedenmann et al. 2009). Nach 24 Stunden hat GFP seine volle Fluoreszenz erreicht (Kobayashi et al. 2005). In unseren Versuchen konnte ebenfalls nach 24 Stunden keine weitere Zunahme der Fluoreszenz beobachtet werden. Dabei ist zu sehen, dass einige Zellen stärker als andere fluoreszieren. Ein Grund dafür könnte sein, dass die Zellen während der Transfektion unterschiedliche Mengen des Plasmids aufgenommen haben.

Um festzustellen ob die Nukleofektion der CPC's zu einer stabilen oder transienten Transfektion geführt hat, wurde beobachtet, wie lange nach der Transfektion fluoreszierende Zellen zu sehen waren. Diese wurden in bestimmten zeitlichen Abständen fotografiert. Hierbei wurde festgestellt, dass nach ca. zwei Wochen keine fluoreszierenden Zellen mehr zu sehen waren.

Zudem wurden die Zellen mit Puromycin behandelt. Dadurch, dass alle Zellen die das Plasmid in sich tragen über eine Resistenz gegenüber Puromycin verfügen, 
sterben nur solche Zellen, welche das Plasmid nicht haben. Nach ca. zwei Wochen waren alle Zellen unter dem Einfluss von Puromycin gestorben.

Anhand dieser Ergebnisse kann festgestellt werden, dass es bei der Transfektion der CPC's mit dem iLenti-GFP-siRNA-Expression-Vektor mittels Nukleofektion zu einer transienten Transfektion kam. Dies bedeutet, dass der Vektor nicht in das zelleigene Genom der CPC's aufgenommen wurde, wie es bei einer stabilen Transfektion der Fall gewesen wäre.

Eine Möglichkeit um eine stabile Transfektion von CPC's zu generieren, wäre die Verwendung eines viralen Vektorsystems. Hierfür geeignet wäre ein von dem menschlichen Immundefizienzvirus 1 (HIV 1) abgeleiteter Lentivirus. Diese Viren zeichnen sich durch eine geringe Cytotoxizität aus und integrieren ihr Genom in die Chromosomen der Zielzellen, was zu einer stabilen Expression führt (Kobayashi et al. 2005).

\subsection{Plasmid-Vergleich}

Um einen möglichst effektiven Knockdown des Transkriptionsfaktors Runx2 in CPC's zu generieren, wurden vier Plasmide mit verschiedenen si-RNA-Sequenzen verglichen. Hierzu wurden CPC's jeweils mit einem der Plasmide transfiziert und nach bestimmten Zeitintervallen die m-RNA aus den Zellen isoliert, um diese mittels der Methode der PCR zu vergleichen.

Die Ergebnisse der PCR zum Vergleich der vier Plasmide mit den vier verschiedenen si-RNA-Sequenzen zeigen, dass alle vier Plasmide einen partiellen Knockdown von Runx2 hervorgerufen haben. Bei allen transfizierten CPC's ist das m-RNA-Level im Vergleich zu dem von nicht-transfizierten CPC's deutlich niedriger. Ein kompletter Knockdown von Runx2 wurde mit keinem der Plasmide erreicht. Bei keinem der Plasmide ist ein Knockdown-Effekt völlig ausgeblieben. Die Plasmide 635 und 1013 haben etwas bessere Knockdown-Ergebnisse geliefert als die Plasmide1472 und 1371.

Im Vergleich führte die Transfektion mit dem Plasmid $635 \mathrm{zu}$ dem niedrigsten m-RNA-level für Runx2. Aufgrund dieses Ergebnisses wurden die weiteren Transfektionen mit dem Plasmid 635 durchgeführt. 


\subsection{Runx2-Knockdown}

Runx2 ist ein wichtiger Regulator der Zelldifferenzierung während der Knochenentwicklung. Schon in mesenchymalen Stammzellen wird Runx2 exprimiert und beeinflusst die weitere Differenzierung dieser Zellen (Jonason et al. 2009). Auch in osteoarthritischem Knorpelgewebe wird Runx2 vermehrt exprimiert. In Chondrozyten aus osteoarthritischem Knorpelgewebe wurde gleichzeitig zu der erhöhten Expression von Runx2 eine erhöhte Expression von MMP-13 festgestellt (Wang et al. 2004). MMP-13 ist an dem Abbau von Kollagen-Typ II, einem Hauptbestandteil der Knorpelmatrix, beteiligt. Diese Ergebnisse deuten auf die wichtige Rolle von Runx2 im Rahmen der Osteoarthritis hin.

Weiterhin gibt es eine Beeinflussung zwischen Runx2 und dem Transkriptionsfaktor Sox9 (Koelling et al. 2009), welcher an der Regulation der embryonalen Knorpel- und Skelettentwicklung beteiligt ist und auch in ausgereiften Chondrozyten exprimiert wird. In osteoarthritischen Chondrozyten hingegen wurde eine verminderte Expression von Sox9 beobachtet (Salminen et al. 2001). Zudem scheint Sox9 die Expression von Kollagen-Typ II zu verstärken (Lefebvre et al. 1997). Durch eine verstärkte Expression von Sox9 in osteoarthritischen Chondrozyten wurde eine verstärkte Expression von Kollagen-Typ II und von Proteoglykanen erreicht, wodurch eine Regeneration der Knorpelmatrix ermöglicht werden könnte (Cucchiarini et al. 2007).

Eine gut zu reproduzierende Methode für einen Knockdown von Runx2 in CPC's ist ein wichtiger Schritt für weitere Untersuchungen dieser Zellen und zum Verständnis der Rolle und des Zusammenspiels von Runx2 und Sox9 im Rahmen der Osteoarthritis.

Die PCR-Ergebnisse für die m-RNA-Level der transfizierten CPC's nach 12 bis 96 Stunden zeigen einen deutlichen Knockdown-Effekt für Runx2 gegenüber der Kontrolle. Im Vergleich mit den Ergebnissen aller Plasmide sieht man, dass die m-RNALevel für Runx2 sich nur minimal unterscheiden. Hier konnte der Knockdown mit diesem Vektor also reproduziert werden. Bei der Betrachtung des zeitlichen Verlaufs ist bei 12 Stunden das niedrigste- und bei 96 Stunden das höchste m-RNA-Level gemessen worden. Insgesamt ist der Unterschied zwischen den unterschiedlichen Zeiten gering.

Die Betrachtung der Western Blot-Ergebnisse zeigt eine teilweise Übereinstimmung mit den Ergebnissen der PCR. Bei allen Zeiten ist kein kompletter Knockdown von 
Runx2 zu sehen. Bei 12, 24 und 48 Stunden ist ein deutlicher Effekt gegenüber der Kontrolle zu sehen. Bei 96 Stunden ist gegenüber der Kontrolle kein Effekt mehr zu erkennen. Bei den Ergebnissen der PCR hingegen ist auch nach 96 Stunden noch ein Knockdown auf Ebene der m-RNA gemessen worden, wenn auch nicht so ausgeprägt wie zu den Zeiten davor.

Dieses Ergebnis lässt darauf schließen, dass es nach 96 Stunden auch noch zu einem Knockdown gekommen ist, welcher aber im Western Blot nicht mehr von der Kontrollbande zu unterscheiden ist.

Der Runx2-Knockdown konnte bis zu 48 Stunden nach der Transfektion, auf der Ebene des Proteins gezeigt werden. Durch die Fotos der fluoreszierenden Zellen wissen wir, dass das Plasmid länger als 96 Stunden in den CPC's ist.

Da das Plasmid aber nur transient transfiziert werden konnte und so nicht in das zelleigene Genom der CPC's aufgenommen wurde, wird es bei einer Teilung der Zelle nicht weitergegeben. Das bedeutet, dass mit zunehmender Zeit immer mehr Zellen in der Kultur sind, welche Runx2 exprimieren. Bei der Selektion dieser Zellen mit Puromycin verringerte sich die Zahl der lebenden Zellen so weit, dass eine Messung des Proteins im Western Blot nicht mehr möglich war.

Es ist zu sehen, dass die Fluoreszenz mit der Zeit schwächer wird. Das könnte bedeuten, dass das Plasmid in der Zelle abgebaut wird oder nach einer gewissen Zeit nicht mehr so stark exprimiert wird.

Möglich wäre auch eine zytotoxische Wirkung, durch eine starke Expression der shRNA, bedingt durch die Aufnahme großer Mengen des Plasmids (Fish und Kruithof 2004). Bei Mäusen führte eine hohe Expression von sh-RNA in der Leber zu einer Leberinsuffizienz und in der Folge zum Tod (Grimm et al. 2006). So könnte es sein, dass die Zellen sterben, obwohl das Plasmid in das Zellgenom eingebaut wurde. Auch beschrieben ist eine durch das Einbringen von si-RNA vermittelte Aktivierung von Interferonen (Sledz et al. 2003), Cytokine welche der viralen Abwehr dienen und unter anderem zu einer Produktion RNA-abbauender Enzyme führen. Dieser Mechanismus könnte erklären, warum die Intensität der Fluoreszenz mit der Zeit abnimmt. Es würde bedeuten, dass weiterhin RNA exprimiert, jedoch auch schnell wieder abgebaut wird.

Abgesehen von den möglichen beschriebenen Nebeneffekten, konnte mit dem iLentiGFP-siRNA-Expression-Vektor ein Runx2-Knockdown auf Proteinebene bis zu 48 Stunden lang nachgewiesen werden. Durch die Schwierigkeit, gleiche Zellmengen 
der transfizierten CPC`s, von unterschiedlichen Zeitabständen nach der Transfektion für den Western Blot zu gewinnen, konnte der Knockdown-Effekt verdeutlicht werden. Obwohl in dem ersten Western Blot bei der 12 und 24 Stunden Probe deutlich mehr Gesamtprotein aufgetragen wurde, bedingt dadurch, dass nach 96 Stunden schon mehr Zellen gestorben waren, ist nach der Immunreaktion mit dem Runx2Antikörper bei 12 und 24 Stunden eine deutlich schwächere Bande auf dem Fotofilm zu sehen als bei der 96 Stunden-Probe und der Kontrolle.

Die Ergebnisse der PCR und des Western Blots zeigen auch, dass der Knockdown von Runx2 mit dem iLenti-GFP-siRNA-Expression-Vektor sicher reproduziert werden konnte. Dadurch ist es möglich die Auswirkungen des Runx2-Knockdowns auf die CPC's zu untersuchen.

\subsection{Effekt des Runx2-Knockdown}

Die Bedeutung des Zusammenspiels von Runx2 und Sox9 wurde schon beschrieben. Ein Knockdown von Runx2 führt zu einer verstärkten Expression von Sox9, was wiederum das chondrogene Potential der CPC`s verstärkt (Koelling et al. 2009). Dies ist ein wichtiger Ansatz bezüglich einer möglichen Regeneration von osteoarthritischem Knorpelgewebe mit Hilfe von CPC's.

Weiterhin wurde beschrieben, dass eine erhöhte Expression von Sox9 in osteoarthrtischen und normalen Chondrozyten zu einer erhöhten Expression von Kollagen-Typ II und von Proteoglykanen führt, wodurch eine Regeneration der Knorpelmatrix möglich sein könnte (Cucchiarini et al. 2007).

Die Ergebnisse dieser Arbeit zeigen einen 48 Stunden andauernden Knockdown von Runx2 im Western Blot. Um die Auswirkungen auf Sox9 zu untersuchen, wurde die Immunreaktion mit einem Sox9-Antikörper durchgeführt. Das Ergebnis zeigt, dass in CPC's die Expressionsrate von Sox9 bei einer niedrigen Expression von Runx2 ansteigt und dass bei einer sich wieder erhöhenden Runx2-Expression die Sox9Expression wieder absinkt. Dieser Zusammenhang konnte in dieser Arbeit erstmals im Western Blot gezeigt werden. Nach 96 Stunden ist also, äquivalent zu den Ergebnissen der Immunreaktion gegen Runx2, eine Veränderung der Proteinmenge von Sox9 auf dem Fotopapier zu sehen. Die Tatsache, dass die Bande für Sox9 bei 96 Stunden deutlich schwächer wird, genauso wie die für Runx2 zu diesem Zeitpunkt deutlich stärker wird zeigt, dass sich die beiden Transkriptionsfaktoren auch im Hin- 
blick auf die jeweilige Proteinmenge, bei einer Herabregulation von Runx2, umgekehrt proportional beeinflussen.

Das Zusammenspiel von Runx2 und Sox9 konnte mittels des iLenti-siRNAExpression-Vektors beeinflusst werden. Dadurch ist es möglich, mit diesem Vektor weitere Untersuchungen an CPC's vorzunehmen, wie zum Beispiel den Knockdown von Sox9 und dessen Einfluss auf Runx2.

Ein weiterer Schritt wird sein, die durch einen Knockdown verursachten Veränderungen der Expression bestimmter Gene zu untersuchen. Dazu zählen die Gene der typischen Knorpelmatrix-Komponenten, wie zum Beispiel Kollagen-Typ II und Aggrecan, sowie typische Marker von osteoarthritischem Knorpelgewebe, wie zum Beispiel Kollagen-Typ I.

Ziel ist es, die CPC's in Ihrer Expression dauerhaft so zu beeinflussen, dass Sie eine der des hyalinen Knorpels entsprechende Knorpelmatrix sezernieren und damit zu einer Regeneration von osteoarthritischem Knorpelgewebe beitragen können. 


\section{Zusammenfassung}

Osteoarthritis ist unter anderem durch eine Degeneration des Knorpelgewebes in den betroffenen Gelenken gekennzeichnet. Eine vollständige Regeneration von osteoarthritisch verändertem Gelenkknorpel wird mit den aktuellen Behandlungsmethoden nicht erreicht. Chondrogene Progenitor-Zellen können in späten Stadien von Osteoartrithis in dem erkrankten Gewebe gefunden werden. Diese Zellen weisen Stammzelleigenschaften und ein hohes chondrogenes Potential auf. Die Transkriptionsfaktoren Runx2 und Sox9 spielen im Rahmen der Differenzierung dieser Zellen eine wichtige Rolle. Der Knockdown von Runx2 führt zu einem Anstieg von Sox9, was wiederum zu einer Verstärkung des chondrogenen Potentials führt.

Diese Arbeit hatte zum Ziel, mit Hilfe von RNA-Interference eine reproduzierbare Methode für einen Knockdown von Runx2 in Chondrogenen Progenitor-Zellen zu erreichen. Dazu wurde der iLenti-GFP-siRNA-Expression-Vektor verwendet. Im ersten Schritt konnte mit Hilfe der Nukleofektion eine ausreichend hohe Transfektion der CPC's, mit dem iLenti-GFP-siRNA-Expression-Vektor, erreicht werden.

Durch die PCR mit isolierter m-RNA aus transfizierten CPCs, konnten vier verschiedene si-RNA-Sequenzen jeweils 72 Stunden nach der Transfektion miteinander verglichen werden. Bei allen wurde ein Knockdown von Runx2 gegenüber normalen CPC's festgestellt.

Um den Knockdown von Runx2 zeitlich nachzuvollziehen, beziehungsweise um zu prüfen, wie lange der Knockdown anhält, wurde 12, 24, 48 und 96 Stunden nach der Transfektion eine PCR durchgeführt. Zu allen Zeiten wurde ein Knockdown von Runx2 gegenüber normalen CPC's fetsgestellt. Dabei war das gemessene m-RNALevel bei 12 Stunden am geringsten und wurde bis hin zu 96 Stunden mehr.

Um den Knockdown von Runx2 auch auf der Ebene des Proteins nachzuweisen wurden Western Blots durchgeführt. Hier konnte ein Knockdown bis zu 48 Stunden festgestellt werden. Die Ergebnisse des Western Blots wurden reproduziert, was ein wichtiges Ziel dieser Arbeit war.

Weiterhin wurde der Einfluss des Knockdowns von Runx2 auf Sox9 im Western Blot untersucht. Äquivalent zum Knockdown von Runx2 konnte hier bis 48 Stunden nach der Transfektion ein Anstieg von Sox9 gezeigt werden. Dieses Ergebnis bestätigt das Zusammenspiel dieser beiden wichtigen Transkriptionsfaktoren in CPC's und zeigt dies erstmals im Western Blot. 


\section{Abbildungsverzeichnis}

\begin{tabular}{|c|c|c|}
\hline $\begin{array}{l}\text { Abbildung } \\
1\end{array}$ & $\begin{array}{l}\text { Gelenkknorpel im Längsschnitt schematisch und mikrosko- } \\
\text { pisch. Oberfächliche Zone (b), mittlere Zone (c) , tiefe Zone } \\
\text { (d) und tiefe mit calzifizierter Zone (e) }\end{array}$ & S. 2 \\
\hline $\begin{array}{l}\text { Abbildung } \\
2\end{array}$ & Chondrogenese & S. 5 \\
\hline $\begin{array}{l}\text { Abbildung } \\
3\end{array}$ & $\begin{array}{l}\text { Gewebe von späten Stadien der Osteoarthritis zeigt Fissuren } \\
\text { an der Oberfläche, Zell-Cluster-Bildung und Brüche in der Ti- } \\
\text { demark (Pfeil), welche mit Blutgefäßen gefüllt sind B: Zellen } \\
\text { (1-3) welche durch die Tidemark in die Knorpelmatrix migrie- } \\
\text { ren }\end{array}$ & S. 11 \\
\hline $\begin{array}{l}\text { Abbildung } \\
4\end{array}$ & $\begin{array}{l}\text { Relative m-RNA-Level von Sox9, Kollagen-Typ II, Runx2 und } \\
\text { Kollagen-Typ I für Chondrozyten (A), CPC`s (B) und Osteo- } \\
\text { blasten (C) }\end{array}$ & S. 11 \\
\hline $\begin{array}{l}\text { Abbildung } \\
5\end{array}$ & RNA-Interference & S.16 \\
\hline $\begin{array}{l}\text { Abbildung } \\
6\end{array}$ & Plasmidvektor & S.19 \\
\hline $\begin{array}{l}\text { Abbildung } \\
7\end{array}$ & iLenti-GFP-siRNA-Expression-Vektor (Biocat \# LV016-ABM) & S. 21 \\
\hline $\begin{array}{l}\text { Abbildung } \\
8\end{array}$ & $\begin{array}{l}\text { Erste Versuche: CPC`s in einer } 75 \mathrm{~cm}^{2} \text {-Zellkulturflasche } 24 \\
\text { Stunden nach Transfektion von } 250.000 \text { Zellen (A),CPC`s mit } \\
\text { Maßstabsbalken zur Größeneinschätzung (B) }\end{array}$ & S. 37 \\
\hline $\begin{array}{l}\text { Abbildung } \\
9\end{array}$ & $\begin{array}{l}\text { CPC's } 12 \text { (A) und } 24 \text { (B) Stunden nach der Transfektion von } \\
600.000 \text { Zellen in } 25 \mathrm{~cm}^{2} \text {-Zellkulturflaschen. }\end{array}$ & S. 38 \\
\hline $\begin{array}{l}\text { Abbildung } \\
10\end{array}$ & $\begin{array}{l}\text { CPC`s } 72 \text { Stunden }(A), 5 \text { Tage }(B), 7 \text { Tage }(C) \text { und } 13 \text { Tage } \\
\text { (D) nach der Transfektion }\end{array}$ & S. 40 \\
\hline $\begin{array}{l}\text { Abbildung } \\
11\end{array}$ & $\begin{array}{l}\text { Transfizierte CPC`s } 48 \text { Stunden nach Transfektion und mit } \\
\text { Puromycin selektioniert }\end{array}$ & S. 41 \\
\hline $\begin{array}{l}\text { Abbildung } \\
12\end{array}$ & $\begin{array}{l}\text { Säulendiagramm der relativen m-RNA-Level von Runx2 in } \\
\text { CPC's nach Transfektion der Zellen mit den vier verschiede- } \\
\text { nen Plasmiden und von normalen CPC's als Kontrolle }\end{array}$ & S. 42 \\
\hline $\begin{array}{l}\text { Abbildung } \\
13\end{array}$ & $\begin{array}{l}\text { Relative m-RNA-Level für Runx2 der mit dem Plasmid } 635 \\
\text { transfizierten CPC's nach } 12 \text { bis } 96 \text { Stunden und normaler } \\
\text { CPC`s }\end{array}$ & S. 43 \\
\hline $\begin{array}{l}\text { Abbildung } \\
14\end{array}$ & $\begin{array}{l}\text { Kontrolle: Western Blot mit nicht-transfizierten CPC`s. } \\
\text { Coomassie-Färbung (A), Fotofilm mit Runx2-Banden bei ca. } \\
57 \text { kDa (B) und Fotofilm mit alpha-Tubulin-Banden bei ca. } 55 \\
\text { kDa (C) }\end{array}$ & S. 44 \\
\hline $\begin{array}{l}\text { Abbildung } \\
15\end{array}$ & $\begin{array}{l}\text { Western Blot mit CPCs 12, 24, } 48 \text { und } 96 \text { Stunden nach } \\
\text { Transfektion mit dem iLenti-GFP-siRNA-Expression-Vektor. } \\
\text { Coomassie-Färbung (A), Fotofilm mit Runx2-Banden (B) und } \\
\text { Fotofilm mit alpha-Tubulin-Banden (C) }\end{array}$ & S. 44 \\
\hline $\begin{array}{l}\text { Abbildung } \\
16\end{array}$ & $\begin{array}{l}\text { Western Blot mit CPC's 12, 24, } 48 \text { und } 96 \text { Stunden nach } \\
\text { Transfektion mit dem iLenti-GFP-siRNA-Expression-Vektor. } \\
\text { Coomassie-Färbung (A), Fotofilm mit Runx2-Banden (B) Foto- } \\
\text { film mit alpha-Tubulin-Banden (C) und Fotofilm mit Runx2- } \\
\text { Banden nicht-transfizierter CPC's als Kontrolle }\end{array}$ & S. 45 \\
\hline
\end{tabular}




\begin{tabular}{|l|l|l|}
\hline $\begin{array}{l}\text { Abbildung } \\
17\end{array}$ & $\begin{array}{l}\text { Western Blot mit CPC's 12, 24, 48 und 96 Stunden nach } \\
\text { Transfektion mit dem iLenti-GFP-siRNA-Expression-Vektor } \\
\text { und CPC's ohne den Vektor als Kontrolle (K). Coomassie- }\end{array}$ & \\
& $\begin{array}{l}\text { Färbung (A), Fotofilm mit Runx2-Banden (B) und Fotofilm mit } \\
\text { alpha-Tubulin-Banden (C) }\end{array}$ & \\
\hline $\begin{array}{l}\text { Abbildung } \\
18\end{array}$ & $\begin{array}{l}\text { Western Blot mit CPC`s 12, 24, 48 und 96 Stunden nach } \\
\text { Transfektion mit dem iLenti-GFP-siRNA-Expression-Vektor. } \\
\text { Coomassie-Färbung (A), Fotofilm mit Runx2-Banden (B), Fo- } \\
\text { tofilm mit alpha-Tubulin-Banden (C) und Fotofilm mit Sox9- } \\
\text { Banden (D) }\end{array}$ \\
\hline
\end{tabular}

\section{Tabellenverzeichnis}

\begin{tabular}{|l|l|l|}
\hline Tabelle 1 & Primer & S. 27 \\
\hline Tabelle 2 & Probenvorbereitung für die PCR & S. 28 \\
\hline Tabelle 3 & Protokoll der PCR & S. 28 \\
\hline Tabelle 4 & Antikörper & S. 35 \\
\hline
\end{tabular}




\section{Literaturverzeichnis}

Aigner, T, E Bartnik, F Sohler and R Zimmer (2004). "Functional genomics of osteoarthritis: on the way to evaluate disease hypotheses." Clin Orthop Relat Res (427 Suppl): S138-143.

Akiyama , H (2005). "Osteo-chondroprogenitor cells are derived from Sox9 expressing precursors." Proc Natl Acad Sci 102(41): 14665-14670.

Akiyama, H, M C Chaboissier, J F Martin, A Schedl and B de Crombrugghe (2002). "The transcription factor Sox9 has essential roles in successive steps of the chondrocyte differentiation pathway and is required for expression of Sox 5 and Sox6." Genes Dev 16(21): 2813-2828.

Benito, M J (2005). "Synovial tissue inflammation in early and late osteoarthritis." Ann Rheum Dis 64(9): 1263-1267.

Billinghurst, R C, L Dahlberg, M lonescu, A Reiner, R Bourne, C Rorabeck, P Mitchell, J Hambor, O Diekmann, H Tschesche, J Chen, H Van Wart and A R Poole (1997). "Enhanced cleavage of type II collagen by collagenases in osteoarthritic articular cartilage." J Clin Invest 99(7): 1534-1545.

Buckwalter, J A and S Lohmander (1994). "Operative treatment of osteoarthrosis. Current practice and future development." J Bone Joint Surg Am 76(9): 1405-1418.

Castanotto, D and J J Rossi (2009). "The promises and pitfalls of RNA-interferencebased therapeutics." Nature 457(7228): 426-433.

Cawston, T E and A J Wilson (2006). "Understanding the role of tissue degrading enzymes and their inhibitors in development and disease." Best Pract Res Clin Rheumatol 20(5): 983-1002.

Cheng, A and P G Genever (2010). "SOX9 determines RUNX2 transactivity by directing intracellular degradation." J Bone Miner Res 25(12): 2680-2689.

Cucchiarini, M, T Thurn, A Weimer, D Kohn, E F Terwilliger and H Madry (2007). "Restoration of the extracellular matrix in human osteoarthritic articular cartilage by overexpression of the transcription factor SOX9." Arthritis Rheum 56(1): 158-167. 
Dixit, R, K Dixit and A R Paramez (2010). "Cleidocranial dysplasia." Lung India 27(3): 176-177.

Ducy, P, R Zhang, V Geoffroy, A L Ridall and G Karsenty (1997). "Osf2/Cbfa1: a transcriptional activator of osteoblast differentiation." Cell 89(5): 747-754.

Felson, D T (2006). "Clinical practice. Osteoarthritis of the knee." N Engl J Med 354(8): 841-848.

Fire, A, S Xu, M K Montgomery, S A Kostas, S E Driver and C C Mello (1998). "Potent and specific genetic interference by double-stranded RNA in Caenorhabditis elegans." Nature 391(6669): 806-811.

Fish, R J and E K Kruithof (2004). "Short-term cytotoxic effects and long-term instability of RNAi delivered using lentiviral vectors." BMC Mol Biol 5: 9.

Fitzgerald, J B (2004). "Mechanical Compression of Cartilage Explants Induces Multiple Time-dependent Gene Expression Patterns and Involves Intracellular Calcium and Cyclic AMP." J Biol Chem 279(19): 19502-19511.

Gannon, J M, G Walker, M Fischer, R Carpenter, R C Thompson, Jr. and T R Oegema, Jr. (1991). "Localization of type X collagen in canine growth plate and adult canine articular cartilage." J Orthop Res 9(4): 485-494.

Goldring, M B and S R Goldring (2007). "Osteoarthritis." J Cell Physiol 213(3): 626634.

Goldring, M B and K B Marcu (2009). "Cartilage homeostasis in health and rheumatic diseases." Arthritis Res Ther 11(3): 224.

Goldring, M B, K Tsuchimochi and K ljiri (2006). "The control of chondrogenesis." J Cell Biochem 97(1): 33-44.

Grimm, D, K L Streetz, C L Jopling, T A Storm, K Pandey, C R Davis, P Marion, F Salazar and M A Kay (2006). "Fatality in mice due to oversaturation of cellular microRNA/short hairpin RNA pathways." Nature 441(7092): 537-541. 
Grogan, S P, S Miyaki, H Asahara, D D D'Lima and M K Lotz (2009). "Mesenchymal progenitor cell markers in human articular cartilage: normal distribution and changes in osteoarthritis." Arthritis Res Ther 11(3): R85.

Guilak, F, B Fermor, F J Keefe, V B Kraus, S A Olson, D S Pisetsky, L A Setton and J B Weinberg (2004). "The role of biomechanics and inflammation in cartilage injury and repair." Clin Orthop Relat Res(423): 17-26.

Haleem-Smith, H, A Derfoul, C Okafor, R Tuli, D Olsen, D J Hall and R S Tuan (2005). "Optimization of high-efficiency transfection of adult human mesenchymal stem cells in vitro." Mol Biotechnol 30(1): 9-20.

Hall, A C, E R Horwitz and R J Wilkins (1996). "The cellular physiology of articular cartilage." Exp Physiol 81(3): 535-545.

Heinegard, D (2009). "Proteoglycans and more--from molecules to biology." Int J Exp Pathol 90(6): 575-586.

Hill, C L, D G Gale, C E Chaisson, K Skinner, L Kazis, M E Gale and D T Felson (2001). "Knee effusions, popliteal cysts, and synovial thickening: association with knee pain in osteoarthritis." J Rheumatol 28(6): 1330-1337.

Hollander, A P, S C Dickinson and W Kafienah (2010). "Stem Cells and Cartilage Development: Complexities of a Simple Tissue." Stem Cells 28(11): 1992-1996.

Horton, W E, Jr., P Bennion and L Yang (2006). "Cellular, molecular, and matrix changes in cartilage during aging and osteoarthritis." J Musculoskelet Neuronal Interact 6(4): 379-381.

Inada, M, T Yasui, S Nomura, S Miyake, K Deguchi, M Himeno, M Sato, H Yamagiwa, T Kimura, N Yasui, T Ochi, N Endo, Y Kitamura, T Kishimoto and T Komori (1999). "Maturational disturbance of chondrocytes in Cbfa1-deficient mice." Dev Dyn 214(4): 279-290.

Jonason, J H, G Xiao, M Zhang, L Xing and D Chen (2009). "Post-translational Regulation of Runx2 in Bone and Cartilage." J Dent Res 88(8): 693-703. 
Kim, D H, M A Behlke, S D Rose, M S Chang, S Choi and J J Rossi (2005). "Synthetic dsRNA Dicer substrates enhance RNAi potency and efficacy." Nat Biotechnol 23(2): 222-226.

Knudson, C B and W Knudson (1993). "Hyaluronan-binding proteins in development, tissue homeostasis, and disease." FASEB J 7(13): 1233-1241.

Kobayashi, N, J D Rivas-Carrillo, A Soto-Gutierrez, T Fukazawa, Y Chen, N NavarroAlvarez and N Tanaka (2005). "Gene delivery to embryonic stem cells." Birth Defects Res C Embryo Today 75(1): 10-18.

Koelling, S, J Kruegel, M Irmer, J R Path, B Sadowski, X Miro and N Miosge (2009). "Migratory chondrogenic progenitor cells from repair tissue during the later stages of human osteoarthritis." Cell Stem Cell 4(4): 324-335.

Kuettner, K E (1992). "Biochemistry of articular cartilage in health and disease." Clin Biochem 25(3): 155-163.

Lakshmipathy, U, B Pelacho, K Sudo, J L Linehan, E Coucouvanis, D S Kaufman and C M Verfaillie (2004). "Efficient transfection of embryonic and adult stem cells." Stem Cells 22(4): 531-543.

Lane, L B, A Villacin and P G Bullough (1977). "The vascularity and remodelling of subchondrial bone and calcified cartilage in adult human femoral and humeral heads. An age- and stress-related phenomenon." J Bone Joint Surg Br 59(3): 272-278.

Lefebvre, V and P Smits (2005). "Transcriptional control of chondrocyte fate and differentiation." Birth Defects Research Part C: Embryo Today: Reviews 75(3): 200212.

Lefebvre, V, P Li and B de Crombrugghe (1998). "A new long form of Sox5 (L-Sox5), Sox6 and Sox9 are coexpressed in chondrogenesis and cooperatively activate the type II collagen gene." EMBO J 17(19): 5718-5733.

Lefebvre, V, W Huang, V R Harley, P N Goodfellow and B de Crombrugghe (1997). "SOX9 is a potent activator of the chondrocyte-specific enhancer of the pro alpha1(II) collagen gene." Mol Cell Biol 17(4): 2336-2346. 
$\mathrm{Li}, \mathrm{Y}, \mathrm{L} \mathrm{Xu}$ and $\mathrm{B}$ R Olsen (2007). "Lessons from genetic forms of osteoarthritis for the pathogenesis of the disease." Osteoarthritis Cartilage 15(10): 1101-1105.

Loeser, R F (2006). "Molecular mechanisms of cartilage destruction: mechanics, inflammatory mediators, and aging collide." Arthritis Rheum 54(5): 1357-1360.

Longo, U G, S Petrillo, E Franceschetti, A Berton, N Maffulli and V Denaro (2012). "Stem cells and gene therapy for cartilage repair." Stem Cells Int 2012: 168385.

Mankin, H J and J A Buckwalter (1996). "Restoration of the osteoarthrotic joint." J Bone Joint Surg Am 78(1): 1-2.

Martin, J A and J A Buckwalter (2002). "Aging, articular cartilage chondrocyte senescence and osteoarthritis." Biogerontology 3(5): 257-264.

Ng, L J, S Wheatley, G E Muscat, J Conway-Campbell, J Bowles, E Wright, D M Bell, P P Tam, K S Cheah and P Koopman (1997). "SOX9 binds DNA, activates transcription, and coexpresses with type II collagen during chondrogenesis in the mouse." Dev Biol 183(1): 108-121.

Otto, F, A P Thornell, T Crompton, A Denzel, K C Gilmour, I R Rosewell, G W Stamp, R S Beddington, S Mundlos, B R Olsen, P B Selby and M J Owen (1997). "Cbfa1, a candidate gene for cleidocranial dysplasia syndrome, is essential for osteoblast differentiation and bone development." Cell 89(5): 765-771.

Pfaffl, M W (2001). "A new mathematical model for relative quantification in real-time RT-PCR." Nucleic Acids Res 29(9): e45.

Poole, C A (1997). "Articular cartilage chondrons: form, function and failure." J Anat 191 ( Pt 1): 1-13.

Pulai, J I, H Chen, H J Im, S Kumar, C Hanning, P S Hegde and R F Loeser (2005).

"NF-kappa B mediates the stimulation of cytokine and chemokine expression by human articular chondrocytes in response to fibronectin fragments." J Immunol 174(9): 5781-5788.

Ramesar, R S, J Greenberg, R Martin, R Goliath, S Bardien, S Mundlos and P Beighton (1996). "Mapping of the gene for cleidocranial dysplasia in the historical 
Cape Town (Arnold) kindred and evidence for locus homogeneity." J Med Genet 33(6): 511-514.

Salminen, H, E Vuorio and A M Saamanen (2001). "Expression of Sox9 and type IIA procollagen during attempted repair of articular cartilage damage in a transgenic mouse model of osteoarthritis." Arthritis Rheum 44(4): 947-955.

Sandell, L J and T Aigner (2001). "Articular cartilage and changes in arthritis. An introduction: cell biology of osteoarthritis." Arthritis Res 3(2): 107-113.

Sashital, D G and J A Doudna (2010). "Structural insights into RNA interference." Curr Opin Struct Biol 20(1): 90-97.

Singhania, R, N Khairuddin, D Clarke and N A McMillan (2012). "RNA interference for the treatment of papillomavirus disease." Open Virol J 6 : 204-215.

Sledz, C A, M Holko, M J de Veer, R H Silverman and B R Williams (2003).

"Activation of the interferon system by short-interfering RNAs." Nat Cell Biol 5(9): 834-839.

Sock, E, R A Pagon, K Keymolen, W Lissens, M Wegner and G Scherer (2003). "Loss of DNA-dependent dimerization of the transcription factor SOX9 as a cause for campomelic dysplasia." Hum Mol Genet 12(12): 1439-1447.

Steinert, A F, S C Ghivizzani, A Rethwilm, R S Tuan, C H Evans and U Noth (2007). "Major biological obstacles for persistent cell-based regeneration of articular cartilage." Arthritis Res Ther 9(3): 213.

Valdes, A M, M Van Oene, D J Hart, G L Surdulescu, J Loughlin, M Doherty and T D Spector (2006). "Reproducible genetic associations between candidate genes and clinical knee osteoarthritis in men and women." Arthritis Rheum 54(2): 533-539.

Wang, X, P A Manner, A Horner, L Shum, R S Tuan and G H Nuckolls (2004). "Regulation of MMP-13 expression by RUNX2 and FGF2 in osteoarthritic cartilage." Osteoarthritis Cartilage 12(12): 963-973.

Watson, JD, M Gilman, J Witkowski, M Zoller in "Rekombinierte DNA.", James D Watson, 2. Aufl., Spektrum , Akad. Verl., Heidelberg, 1993, S 66 
Wiedenmann, J, F Oswald and G U Nienhaus (2009). "Fluorescent proteins for live cell imaging: opportunities, limitations, and challenges." IUBMB Life 61(11): 10291042.

Wuelling, M and A Vortkamp (2009). "Transcriptional networks controlling chondrocyte proliferation and differentiation during endochondral ossification." Pediatr Nephrol 25(4): 625-631. 


\section{Lebenslauf}

Mein Name ist Moritz Klein. Ich wurde am 08.02.1983 in Siegburg, als Sohn von Dr. Heinz Dieter Klein und Birgit Klein, geboren.

Von 1989 bis 1998 besuchte ich die Freie Waldorfschule in Bonn. Anschließend wechselte ich auf das Gymnasium Otto-Kühne-Schule in Bonn-Bad Godesberg, wo ich 2002 mein Abitur mit der Note „3.0“ bestand. Es folgte ein neunmonatiger Zivildienst am Universitäts-Klinikum Bonn auf einer neurologischen Intensivstation (Stroke-Unit).

Ab 2004 studierte ich ein Semester Mineralogie an der Universität zu Köln. Ab dem Wintersemester 2004 studierte ich Zahnmedizin an der Georg-August-Universität Göttingen und bestand im Jahr 2010 das Staatsexamen mit der Note „sehr gut“. Anschließend arbeitete ich an meiner Dissertation bei Prof. Dr. med. N. Miosge, Abteilung Prothetik, AG orale Biologie und Geweberegeneration.

Im Mai 2011 folgte eine Anstellung als Vorbereitungsassistent in der Praxis für Implantologie und Zahnheilkunde in Murnau am Staffelsee, Bayern. Seit dem 15.08.12 bin ich als Vorbereitungsassistent in der Praxis Dr. Binia, Dr. Wölfling in Monheim am Rhein angestellt. 


\section{Danksagung}

Ich danke Prof. Miosge für die Anregung zu dieser Arbeit und die gute und persönliche Betreuung.

Des Weiteren bedanke ich mich bei allen Mitarbeitern der Abteilung Prothetik, AG orale Biologie und Geweberegeneration für die nette Zusammenarbeit und Hilfsbereitschaft. 